MENOUFIA JOURNAL OF ANIMAL, POULTRY AND

FISH PRODUCTION

https://mjapfp.journals.ekb.eg/

\title{
INFLUENCE OF DIETARY POLYZYME IN LOW CRUDE PROTEIN DIET ON THE PERFORMANCE OF WHITE MOLAR DUCKS
}

\author{
A. M. H. Abou - Ashour, S. A. A. Abd El- Rahman, Manal K. Abou El-Naga, \\ N. S. Elfergany and Eman A. Hussein*
}

Department of Poultry and Fish production, Faculty of Agriculture, Menoufia University, Shibin El Kom, Egypt.

Received: Dec. 14, $2021 \quad$ Accepted: Jan. 23, 2022

\begin{abstract}
The present experiment was conducted to investigate the effect of Polyzyme supplementation in low crude protein diets on Molar ducks on growth performance, carcass traits, some blood serum parameters, some histomorphological measurements, economic efficiency and European efficiency index. Two hundred and forty, un-sexed one day old White Molar duck chicks were used and assigned to eight groups nearly similar in average body weight, ( 3 replicates of 10 birds each). Polyzyme was added at the levels $(0,1,2$ and $3 \mathrm{~g} / \mathrm{Kg}$ diet $)$ to the low crude protein content that was used as a negative control (18 and $16 \% \mathrm{CP}$ ) and the diet with normal content of crude protein, which was used as the positive control (20 and $18 \% \mathrm{CP}$ ) treatment during the periods of starter (1-21 days) and finishing (2270 days), respectively. Results indicated that, ducks fed negative control $+3 \mathrm{~g}$ Polyzyme/ Kg diet having the significantly higher body weight compared to the control groups. Birds fed the negative control diet with different levels of polyzyme had significantly $(\mathrm{P} \leq 0.05)$ consumed more feed than the negative control diet without supplementation at 10 weeks of age. Feed conversion ratio (FCR) and performance index (PI) were improved in birds fed negative control diet with $3 \mathrm{~g}$ Polyzyme/ $\mathrm{Kg}$ diet, $\left(\mathrm{T}_{4}\right)$. Addition of graded levels of Polyzyme to Molar diets was significantly affecting some carcass traits and increased both serum glucose and AST activity, cholesterol, triglycerides and total lipids compared to the negative control group but significantly reduced serum createnine. Morphological sections of Molar small intestine revealed that villi height, width and villi height : villi width are significantly increased with the Polyzyme supplementation levels up to the level of $3 \mathrm{~g} / \mathrm{kg}$ diet and tend to decrease after that, but still better than the negative control group. In general, and through the results obtained from feeding White Molar duck chicks from one day to 10 weeks of age on low crude protien diets (18 and 16\%) with addition of different levels of commercial Polyzyme mixture (1, 2 and $3 \mathrm{~g} / \mathrm{Kg}$ diet) improved growth performance due to increased activity of the small intestine and rate of nutrient absorption. The european efficiency ratio and performance index were improved when adding $3 \mathrm{~g}$ Polyzyme/ $\mathrm{Kg} \operatorname{diet}\left(4^{\text {th }}\right.$ treatment $)$, while the economic efficiency and relative economic efficiency were better (1.56 and 110.64, respectively) in the $2^{\text {nd }}$ treatment which chicks fed low crude protein diet $+1 \mathrm{~g}$ Polyzyme compared to the other trearments.
\end{abstract}

Keywords: Multi - enzyme, performance, carcass trairs, some blood parameters, intestinal morphology and ducks

\section{INTRODUCTION}

Protein in modern poultry production practice is predominantly sourced from soybean meal (SBM), which is high in protein with wellbalanced amino acids (AA) coupled with high digestibility (Ndazigaruye et al., 2019). This meal represented about approximately $80 \%$ of the protein and amino acid requirements of all types of poultry in all life stages. Poultry needs a specific quantity and balance of essential amino acids (EAA) and nitrogen (for synthesis of nonessential amino acids, NEAA) rather than crude protein (NRC, 1994). Chickens fed the standard levels of dietary protein can synthesize NEAA from excess EAA. However, when low-protien (LP) diets are used, less EAA is available for NEAA synthesis. Therefore, reducing dietary crude protein without deleterious effects on broiler performance is a great challenge for broier nutrientitionist. Not only reduced protein regimes diet in poultry nutrition is considered an alternative application to reduce feeding cost, but also to reduce the environmental pollution (Kobayashi et al., 2013). Generally, feeding low crude protein (Low-CP) diet increases the fat content, while, reducing the energy density

\footnotetext{
* Corresponding authar: eman-hussien@ agri.menofia.edu.eg
} 
decreased the fat content and protein increases deposition in the carcass (Zhan et al., 2007). Feed utilization can be met with inclusion of enzymes, antimicrobial, probiotics, prebiotic or natural products (Al-khalifah, 2018).

Exogenous enzyme blends containing various combinations of amylase, protease, xylanase, glucanase, cellulase, mannanase, pectinase and phytase have been assessed in chickens diets which contain high levels of soluble non-starch polysaccharides (NSP), low protein level and found to improve nutrients digestibility and bird growth (Law et al., 2019 and Giacobbo et al., 2021). Therefore, exogenous proteases enzyme have been introduced into livestock feed to improve its nutritive value (Cowieson and Roos, 2016), use of single protease is still under investigation for wide spread application. Several enzymes are commercially available and their use has significantly increased in corn-SBM based diets to improve growth performance of broiler chickens through improved protein and amino acid digestibility (Selim et al., 2016 and Ndazigaruye et al., 2019). Dietary enzyme can facilitate the utilization of protein that are other wise unavailable to the animal, especially when feed ingredients are of low quality and /or have low bioavailability (Kocher et al., 2002).

It has been reported that dietary enzyme enhances weight gain and feed efficiency by improving amino acid content and energy utilization and reducing proteolytic fermentation, bacterial toxins and the amount of nutrients executed in feces, thereby reducing potential environmental pollutants (Mahmood et al., 2017). Therefore, this study was aimed to evaluate the effect of adding Polyzyme (multienzyme) to low crude protein diets to reduce feeding cost and to improve duck performance, carcass traits, some blood components and histological intestine parameters and economical efficiency.

\section{MATERIALS AND METHODS}

The present study was conducted at a private farm in Sadat City, Menoufia Governorate, Egypt, throughout the experimental period from July to September 2018. Two hundred and forty, unsexed one day old White Molar duck chicks (obtained from Mesangere Company for ducks), were used in this study, grown over 70 days. Ducks were individually wing-banded, weighed and randomly assigned to eight groups nearly similar in average body weight, (3 replicates of 10 birds each), kept in a separate pen, reared under similar management and hygienic conditions. Feed and water were provided adlibitum during the experimental period (70 days). Artificial light and day lights were used to provide 24 hour photo period. Polyzyme* was added at the levels $(0,1,2$ and $3 \mathrm{~g} / \mathrm{Kg}$ diets) to the low crude protein content that was used as negative control (18 and $16 \% \mathrm{CP}$ ) and with the normal content of crude protein, which was used as the positive control (20 and $18 \% \mathrm{CP}$ ) during the periods of starter (1-21 days) and finisher (22-70 days), respectively (Table 1). Birds received their diets to save the nutrient requirements according to the NRC (1994) recommendations.

Body weight (BW), body weight gain (BWG), feed intake (FI) and mortality were weekly recorded. Feed conversion ratio (FCR, g feed /g gain) was calculated every week during the experimental period. Performance index (PI) was calculated according to North (1981), where: $\mathrm{PI}=$ live body weight, $\mathrm{kg} \times 100 /$ feed conversion ratio. European efficiency index (EEI) was calculated also as cited by Soltan and Kusainova (2012), where: EEI = (Mean BW, kg $\times$ Livability, \%) / (Marketing age, days $\times$ FCR) $\times$ 100.

*Xylanase 2000000U; Protease 375000U; Lipase 25000U; Pectanase 120000U; Mannase 100000U; Amylase 750000U; Cellulase 200000U; Phytase 25000U; B Glucanase 200000U and Galctocidasse 200000U/0.5 Kg polyzyme. 
Table 1: Composition and calculated analysis of the experimental diets fed during starting $(1-21)$ and finishing periods (22 - 70) days of age.

\begin{tabular}{|c|c|c|c|c|}
\hline \multirow{2}{*}{ Ingredients } & \multicolumn{2}{|c|}{ Negative control diets } & \multicolumn{2}{|c|}{ Positive control diets } \\
\hline & Starter & Finisher & Starter & Finisher \\
\hline Yellow corn, $8.5 \%$. & 68.19 & 71.07 & 61.50 & 68.19 \\
\hline Soybean meal, $44 \%$. & 27.75 & 21.85 & 33.49 & 27.75 \\
\hline Vegetable oil. & - & - & 1.05 & - \\
\hline Wheat bran, $12 \%$. & - & 3.00 & - & - \\
\hline Mono - Calcium phosphate. & 1.60 & 1.60 & 1.55 & 1.60 \\
\hline Limestone, ground. & 1.70 & 1.70 & 1.68 & 1.70 \\
\hline Vitamins and minerals mixture ${ }^{1}$. & 0.30 & 0.30 & 0.30 & 0.30 \\
\hline Salt (Sodium chloride). & 0.30 & 0.30 & 0.30 & 0.30 \\
\hline DL- Methionine ${ }^{2}$ & 0.16 & 0.18 & 0.13 & 0.16 \\
\hline Total & 100 & 100 & 100 & 100 \\
\hline \multicolumn{5}{|l|}{ Calculated analysis ( air dry basis) ${ }^{3}$ : } \\
\hline Crude protein, $\%$ & 18.01 & 16.01 & 19.96 & 18.01 \\
\hline ME, $\mathrm{k} \mathrm{cal} / \mathrm{kg}$ diet. & 2906 & 2908 & 2902 & 2906 \\
\hline $\mathrm{C} / \mathrm{P}$ ratio. & 161 & 182 & 145 & 161 \\
\hline Calcium, $\%$ & 0.99 & 0.99 & 0.99 & 0.99 \\
\hline Available phosphorous, $\%$ & 0.47 & 0.47 & 0.47 & 0.47 \\
\hline \multicolumn{5}{|c|}{$\begin{array}{l}{ }^{\mathrm{T}} \text { Vitamins and minerals mixture at } 0.30 \% \text { of the diet supplies the following/ kg of the diet: Vit. A, } 12000 \mathrm{IU} ; \mathrm{Vi} \\
\mathrm{D}_{3}, 2500 \mathrm{IU} \text {; Vit. E, } 10 \mathrm{mg} \text {; Vit. } \mathrm{K}_{3}, 3 \mathrm{mg} \text {; Vit } \mathrm{B}_{1}, 1 \mathrm{mg} \text {; Vit. } \mathrm{B}_{2}, 4 \mathrm{mg} \text {; Pantothenic acid, } 10 \mathrm{mg} \text {;Nicotinic acid, } 2 \\
\mathrm{mg} \text {; Folic acid, } 1 \mathrm{mg} \text {; Biotin, } 0.05 \mathrm{mg} \text {; Niacin, } 40 \mathrm{mg} \text {; Vit. } \mathrm{B}_{6}, 3 \mathrm{mg} \text {; Vit } \mathrm{B}_{12}, 0.02 \mathrm{mg} \text {; Choline chloride, } 400 \mathrm{mg} \\
\mathrm{Mn}, 62 \mathrm{mg} \text {; Fe, } 44 \mathrm{mg} \text {; Zn, } 56 \mathrm{mg} ; \mathrm{I}, 1 \mathrm{mg} \text {; Cu, } 5 \mathrm{mg} \text { and Se, } 0.01 \mathrm{mg} \text {. } \\
{ }^{2} \mathrm{DL} \text { - Methionine: } 98 \% \text { feed grade }(98 \% \text { Methionine). }\end{array}$} \\
\hline 33 Calculated according to NRC (1994). & & & & \\
\hline
\end{tabular}

At the end of the experiment (10 weeks of age), 6 birds from each treatment around the average live body weight were randomly chosen, fasted for about 12 hours, weighed and slaughtered to complete bleeding, followed by plucking the feathers. Carcass without giblets and some giblets (liver, heart and gizzard) weights were calculated relative to pre-slaughter weight. Dressing percentage was calculated as following: Dressing $\%=$ Empty carcass weight / pre-slaughter weight $\times 100$.

Individual blood samples from the same slaughtered birds for each dietary treatment were collected into tubes without heparin and serum was separated by centrifugation at $3000 \mathrm{rpm}$ for 15 minutes and frozen at $-20{ }^{\circ} \mathrm{C}$ until analysis. Serum total protein, tri-glyceride, lipids, cholesterol, createnine, glucose and albumin were determined using commercial kits. Also, liver enzymes including aspartate transaminase (AST) and alanine transaminase (ALT) were colorimetrically estimated.
The small intestines of chicks were removed immediately, after slaughtering and segments of approximately $2 \mathrm{~cm}$ were taken from duodenum, jejunum and ileum at 70 days of age for histological analysis. Segments referred to the midpoint of the duodenum (from gizzard to pancreo-biliary duct, duodenum), jejunum (the midpoint between the entry of the common bile duct and the Meckel's diverticulum), and ileum (from Meckel's diverticulum to ileocecal junction) were gently flushed and rinsed with $0.9 \%$ physiological saline and then fixed in a $4 \%$ neutral-buffered formalin solution for histological study. Intestinal samples were transferred from formaldehyde after dehydration by passing tissue through a series of alcohol solutions, cleared by xylene and were embedded in paraffin. All samples were sectioned at $5-\mu \mathrm{m}$ thickness using a rotary microtome. Sections were sequentially transferred to glass slides and stained with Hematoxylin and Eosin (H and E). After being dried, sections were analyzed under a light 37 microscope. Morphometric 
measurements were performed on 9 villi chosen from each sample. The height of intestinal villi was measured from the tip to the base of villi at the opening crypt, and the villus width was measured at its midpoint (Geyra et al., 2001).

The economic efficiency of the experimental diets used in the present study was calculated from the input - output analysis (Heady and Jensen, 1954), assuming that the other head costs were constant.

Data were statistically analyzed by the completely randomized design using SPSS, (2011) program and the differences among means were determined using Duncan's multiple range test (Duncan, 1955). Percentages were transformed to the corresponding arcsine values before performing statistical analysis (Snedecor and Cochran, 1982). The model applied was: Yij $=\mu+\alpha i+$ Eij, where: Yij= an observation, $\mu=$ Overall mean, $\alpha \mathrm{i}=$ effect of treatment $(\mathrm{I}=1$, $2,3,4 \ldots 8)$, and $\mathrm{Eij}=$ Experimental random error.

\section{RESULTS AND DISCUSSION}

\section{Body weight and daily body weight gain:}

Effect of dietary different levels of multienzyme supplementation in negative and positive diets on body weight and average daily gain of White Molar ducks at 3 and 10 weeks of age are shown in Table (2). The results showed that chicks fed low crude protein, without multi enzyme (T1) had significantly lower $(\mathrm{P} \leq 0.05)$ BW (879.8 g), and ADG (39.62g) compared to the positive control group without multi-enzyme, (T5); (1042.57 and 47.37g), respectively at 3 weeks of age.

In general, dietary multi-enzyme significantly increased $(\mathrm{P} \leq 0.05)$ body weight and daily gain in White Molar ducks at 3 week of age. Ducks fed negative control supplemented with $3 \mathrm{~g}$ multienzyme/ Kg diet (T4) having the significantly higher body weight (1034.17g), followed by those fed $2 \mathrm{~g}$ and $1 \mathrm{~g}$ multi-enzyme/ $\mathrm{Kg}$ diet (1010.53 and 972.53g, respectively) compared to 1015.60, 999.17 and 1001.23g in chicks fed the positive control diet with $1 \mathrm{~g}, 2 \mathrm{~g}$ and $3 \mathrm{~g}$ multienzymes/ Kg diet (T6, T7 and T8), respectively. Also, data of daily gain was significantly $(\mathrm{P} \leq$ $0.05)$ increased in negative control group $+3 \mathrm{~g}$ multi-enzyme/ Kg diet ( $\mathrm{T} 4,46.98 \mathrm{~g}$ ) compared to $45.40 \mathrm{~g}$ in the 8 th group at 3 weeks of age.

Table 2: Body weight and body weight gain (g) of White Molar ducks fed low and normal crude protein diets supplemented with different levels of Polyzyme at 3 and 10 weeks of age (Means \pm S. E).

\begin{tabular}{|c|c|c|c|c|}
\hline \multirow{2}{*}{ Dietary treatments } & \multicolumn{2}{|c|}{ Body weight, g. } & \multicolumn{2}{c|}{ Body weight gain, d/g. } \\
\cline { 2 - 5 } & 3 weeks & 10 weeks & $0-3$ weeks & $0-10$ weeks \\
\hline $\mathrm{T}_{1 \text { (Negative control) }}$ & $879.8^{\mathrm{d}} \pm 9.58$ & $3546.47^{\mathrm{d}} \pm 37.46$ & $39.62^{\mathrm{c}} \pm 0.46$ & $49.98^{2,3 \mathrm{~d}} \pm 0.53$ \\
\hline $\mathrm{T}_{2}$ & $972.53^{\mathrm{c}} \pm 11.84$ & $4079.13^{\mathrm{c}} \pm 34.35$ & $44.04^{\mathrm{c}} \pm 0.56$ & $57.59^{\mathrm{bc}} \pm 0.49$ \\
\hline $\mathrm{T}_{3}$ & $1010.53^{\mathrm{b}} \pm 10.88$ & $4181.17^{\mathrm{ab}} \pm 28.17$ & $45.85^{\mathrm{ab}} \pm 0.52$ & $59.05^{\mathrm{b}} \pm 0.40$ \\
\hline $\mathrm{T}_{4}$ & $1034.17^{\mathrm{a}} \pm 13.58$ & $4312.37^{\mathrm{a}} \pm 37.22$ & $46.98^{\mathrm{a}} \pm 0.65$ & $60.92^{\mathrm{a}} \pm 0.53$ \\
\hline $\mathrm{T}_{5 \text { (Positive control) }}$ & $1042.57^{\mathrm{a}} \pm 9.57$ & $4191.37^{\mathrm{ab}} \pm 30.01$ & $47.37^{\mathrm{a}} \pm 0.45$ & $59.19^{\mathrm{b}} \pm 0.96$ \\
\hline $\mathrm{T}_{6}$ & $1015.60^{\mathrm{b}} \pm 13.16$ & $4163.90^{\mathrm{b}} \pm 35.69$ & $46.07^{\mathrm{ab}} \pm 0.63$ & $58.80^{\mathrm{b}} \pm 50.77$ \\
\hline $\mathrm{T}_{7}$ & $999.17^{\mathrm{b}} \pm 11.91$ & $4047.87^{\mathrm{c}} \pm 46.46$ & $45.31^{\mathrm{b}} \pm 0.57$ & $57.15^{\mathrm{bc}} \pm 0.66$ \\
\hline $\mathrm{T}_{8}$ & $1001.23^{\mathrm{b}} \pm 12.64$ & $4015.10^{\mathrm{c}} \pm 35.80$ & $45.40^{\mathrm{b}} \pm 0.60$ & $56.68^{\mathrm{c}} \pm 0.51$ \\
\hline Sig. & $*$ & $*$ & $*$ & \\
\hline
\end{tabular}

${ }^{1} \mathrm{~T}_{1}$ : Negative control diet, $\mathrm{T}_{2}$ : Negative control $+1 \mathrm{~g}$ Polyzyme $/ \mathrm{kg}$ diet, $\mathrm{T}_{3}$ : Negative control $+2 \mathrm{~g}$ Polyzyme $/ \mathrm{kg}$ diet, $\mathrm{T}_{4}$ : Negative control $+3 \mathrm{~g}$ Polyzyme $/ \mathrm{kg}$ diet, $\mathrm{T}_{5}$ : Positive control diet, $\mathrm{T}_{6}$ : Positive control $+1 \mathrm{~g}$ Polyzyme $/ \mathrm{kg}$ diet, $\mathrm{T}_{7}$ : Positive control $+2 \mathrm{~g}$ Polyzyme $/ \mathrm{kg}$ diet, $\mathrm{T}_{8}$ : Positive control $+3 \mathrm{~g}$ Polyzyme $/ \mathrm{kg}$ diet.

${ }^{2}$ means \pm S.E. of 3 replicates/ treatment.

${ }^{3} \mathrm{a}, \mathrm{b}, \mathrm{c} \ldots \ldots . . . . \mathrm{etc}$ : Means within the same column with different superscripts are significantly different $(\mathrm{P} \leq 0.05)$. 
On the marketing age (10th weeks), ducks fed the negative control diets supplemented with $3 \mathrm{~g}$ multi-enzyme, (T4) had significantly the highest BW and ADG (4312.37 and $60.92 \mathrm{~g}$ ) followed by chicks fed T3 diet and those fed positive control diet, (T5 and T6 groups), BW values of T3, T5 and T6 were 4181.17, 4191.37 and $4163.90 \mathrm{~g}$ and ADG values being 59.05, 59.19 and $58.80 \mathrm{~g}$, respectively compared to those fed the negative control group, T1 (3546.47 and $49.98 \mathrm{~g}$ ) which recorded the worest performance. These results are in agreement with the finding of Bedford and Morgan (1996) who showed that enzyme addition improves the performance of poultry through reducing the viscosity of intestinal content so, improving the nutritive value of the diet. This is congruent with previous findings (Ndazigarye et al., 2019 and Teymouri and Hasssanabdi, 2021).

Also, Metwally et al. (2020) mentioned that addition of multi-enzyme in wheat and barley based diets had significantly $(\mathrm{P} \leq 0.05)$ increased BWG compared to the control group. Al-harthi et al. (2020) found that phytase supplementation improved BWG in broiler chickens which enhanced broiler body weight gain performance. Supplementation with multi-enzyme tended to improve the nutritive value of corn-soybean diet in broiler chicks (Shirmohammad and Mehri, 2011). On the other hand Castro et al. (2019) and law et al. (2019) observed that the effect of xylanase in diets based on corn and soybean meals (1ow viscosity) did not improved BWG for turkeys (Jamroz et al., 1998).

\section{Feed intake and feed conversion ratio:}

Results of daily feed intake (FI) and FCR of White Molar ducks fed low crude protein diets with different levels of multi-enzyme (1,2 and 3 $\mathrm{g} / \mathrm{Kg}$ diets) during $0-3$ and $0-10$ weeks are summarized in Table (3). Ducks fed the negative control without multi-enzyme supplement $\left(\mathrm{T}_{1}\right)$ had significantly decreased feed intake 78.12 and $148.80 \mathrm{~g}$ compared to the positive control groups $\left(\mathrm{T}_{5}\right)$, being; 86.39 and $158.85 \mathrm{~g}$ during $0-3$ and 0 -10 week of age, respectively. There were significant effects on feed intake due to feeding low crude protein diet supplemented with multi- enzyme (groups $\mathrm{T}_{2}, \mathrm{~T}_{3}$ and $\mathrm{T}_{4}$ ). During the first 3 weeks (starting period), there were no significant differences between groups fed low crude protein diet supplemented with different levels of Polyzyme (1,2 and $3 \mathrm{~g} / \mathrm{Kg}$ diet) and the positive control without supplementation, being $85.57,87.12,88.29$ and $86.39 \mathrm{~g}$ feed / chick/ day. The same trend was noticed between chicks fed the positive control diet supplemented with 1, 2 or $3 \mathrm{~g}$ Polyzyme $(90.34,91.80$ and $91.92 \mathrm{~g}$ feed/ chick/ day) which recorded the highest values, while, the lowest value was recorded in chicks fed the negative control diet $(78.12 \mathrm{~g}$ feed/ chick/ day). During the period ( 0 - 10 weeks), there were no significant differences between chicks fed low crude protein diet supplemented with 2 and $3 \mathrm{~g}$ multi-enzyme. Negative control group supplemented with 2 and 3 g Polyzyme / Kg diet recorded FI the highest values (162.11 and $160.42 \mathrm{~g} /$ chick/ d.), respectively during $0-10$ weeks of age. In overall period (0 - 10 weeks), multi-enzyme supplementation significantly increased feed intake especially in low crude protein diet.

Feed conversion ratio (FCR) was significantly improved by the supplementation. Data revealed that FCR was significantly improved by the supplementation during the experimental period (0-10 weeks of age). At the first period (0 - 3 weeks), there were no significant differences between chicks fed the negative control diet without or with multienzyme supplemented diet and chicks fed the positive control diet $+1 \mathrm{~g}$ Polyzyme/ $\mathrm{Kg}$ diet (1.98, 1.95, 1.91. 1.89 and 1.97, respectively). Ducks fed low protein with $3 \mathrm{~g}$ multi-enzyme/ $\mathrm{Kg}$ diet $\left(\mathrm{T}_{4}\right)$ showed better FCR (2.64) compared to the other levels of multi-enzyme groups, whereas the negative control group showed the worst FCR $\left(2.99, \mathrm{~T}_{1}\right)$ compared to the other treatments in all period ( 0 - 10 weeks of age).

The comparatively more feed intake on enzyme supplementation are supported by Alam et al. (2003) who reported increased feed intake on diet with exogenous enzymes for broilers. Since use of enzyme, decreases mean retention time of digesta in the gizzard and large intestine and increases gut motility. Digesta viscosity and 
microbial fermentation decrease nutrient digestibility and the rate of absorption are increased so that more feed can be consumed. The feed conversion ratio was unallered due to low energy, protein diet and also enzyme supplementation (Dongare et al., 2017). The results of the present study substantiated the findings of Lazaro et al. (2003) and Goli and Shahryar (2015) who reported that fungal enzyme preparation significantly improved the weight gain and feed conversion ratio of birds fed corn, rye, wheat and barley based diets. Responses to enzyme supplementation depend on the bird's age, which is apparently related to both the type of gut microflora present and the physiology of the bird. In old birds, due to enhanced fermentation capacity of the microflora, their intestine have a greater capacity to deal with the effects of high viscosity (Vukicvranjes and Wenk, 1995).

\section{Performance index, (PI \%) and European efficiency index (EEI):}

Experimental results in Table (4) showed the effect of dietary multi-enzyme supplementation to low crude protein diets of White Molar ducks on performance index (PI, \%) and European efficiency index (EEI \%) at 3 and 10 weeks of age. In all levels, results revealed that multienzyme supplementation by the level of $3 \mathrm{~g} / \mathrm{Kg}$ low crude protein diet significantly increased performance index in all periods; (0 - 3, 52.79 $\%$ ) and $162.33 \%$ as an overall period $0-10$ weeks of age in comparison with the negative control group which recorded the worst PI. Overall European efficiency index was improved by polyzyme supplementation, chicks fed low crude protein diet supplemented with $3 \mathrm{~g} / \mathrm{Kg}$ diet was the highest $(233.22 \%)$ followed by those fed the positive control diet without supplementation (221.69\%), while the worest value was noticed in chicks fed low crude protein diet without polyzyme (169.62\%). In general, different levels of multi-enzyme supplementation to the positive control diet recorded the same PI and the significantly was noticed with the supplementation to the negative control diet which revealed that the polyzyme may improve the digestibility of nutrient. These finding are supported with that of Noy and Sklan, (1995) and Uni et al. (1995) who suggested that the inclusion of enzymes during the initial phase of the chickens may improve the digestibility of the nutrients and the performance of the bird.

Table 3: Feed intake and Feed conversion ratio of White Molar ducks fed low and normal crude protein diets supplemented with different levels of Polyzyme at 3 and 10 weeks of age (Means \pm S. E).

\begin{tabular}{|c|c|c|c|c|}
\hline \multirow{2}{*}{$\begin{array}{l}\text { Dietary } \\
\text { treatments }\end{array}$} & \multicolumn{2}{|c|}{$\begin{array}{c}\text { Feed intake } \\
\text { (g/ chick / day) }\end{array}$} & \multicolumn{2}{c|}{$\begin{array}{c}\text { Feed conversion ratio } \\
\text { (g gain/g feed) }\end{array}$} \\
\cline { 2 - 5 } & $0-3$ weeks & $0-10$ weeks & $0-3$ weeks & $0-10$ weeks \\
\hline $\mathrm{T}_{1 \text { (Negative control) }}$ & $78.12^{\mathrm{c}} \pm 0.25$ & $148.80^{\mathrm{c}} \pm 0.19$ & $1.98^{\mathrm{b}} \pm 0.02$ & $2.99^{2,3 \mathrm{a}} \pm 0.03$ \\
\hline $\mathrm{T}_{2}$ & $85.57^{\mathrm{b}} \pm 0.05$ & $154.76^{\mathrm{b}} \pm 0.26$ & $1.95^{\mathrm{b}} \pm 0.03$ & $2.69^{\mathrm{bc}} \pm 0.02$ \\
\hline $\mathrm{T}_{3}$ & $87.12^{\mathrm{b}} \pm 0.04$ & $162.11^{\mathrm{a}} \pm 0.18$ & $1.91^{\mathrm{bc}} \pm 0.02$ & $2.75^{\mathrm{b}} \pm 0.02$ \\
\hline $\mathrm{T}_{4}$ & $88.29^{\mathrm{b}} \pm 0.07$ & $160.42^{\mathrm{a}} \pm 0.25$ & $1.89^{\mathrm{c}} \pm 0.03$ & $2.64^{\mathrm{c}} \pm 0.02$ \\
\hline $\mathrm{T}_{5 \text { (Positive control) }}$ & $86.39^{\mathrm{b}} \pm 0.14$ & $158.85^{\mathrm{ab}} \pm 0.12$ & $1.83^{\mathrm{c}} \pm 0.02$ & $2.70^{\mathrm{bc}} \pm 0.04$ \\
\hline $\mathrm{T}_{6}$ & $90.34^{\mathrm{a}} \pm 0.05$ & $158.05^{\mathrm{ab}} \pm 0.23$ & $1.97^{\mathrm{b}} \pm 0.03$ & $2.70^{\mathrm{bc}} \pm 0.03$ \\
\hline $\mathrm{T}_{7}$ & $91.80^{\mathrm{a}} \pm 0.05$ & $151.32^{\mathrm{cb}} \pm 0.45$ & $2.04^{\mathrm{a}} \pm 0.03$ & $2.66^{\mathrm{c}} \pm 0.03$ \\
\hline $\mathrm{T}_{8}$ & $91.92^{\mathrm{a}} \pm 0.01$ & $152.47^{\mathrm{b}} \pm 0.44$ & $2.03^{\mathrm{a}} \pm 0.03$ & $2.70^{\mathrm{bc}} \pm 0.02$ \\
\hline $\mathrm{Sig}$. & $*$ & $*$ & $*$ & \\
\hline
\end{tabular}

${ }^{\mathrm{I}} \mathrm{T}_{1}$ : Negative control diet, $\mathrm{T}_{2}$ : Negative control $+1 \mathrm{~g}$ Polyzyme $/ \mathrm{kg}$ diet, $\mathrm{T}_{3}$ : Negative control $+2 \mathrm{~g}$ Polyzyme $/ \mathrm{kg}$ diet, $\mathrm{T}_{4}$ : Negative control $+3 \mathrm{~g}$ Polyzyme $/ \mathrm{kg}$ diet, $\mathrm{T}_{5}$ : Positive control diet, $\mathrm{T}_{6}$ : Positive control $+1 \mathrm{~g}$ Polyzyme $/ \mathrm{kg}$ diet, $\mathrm{T}_{7}$ : Positive control $+2 \mathrm{~g}$ Polyzyme $/ \mathrm{kg}$ diet, $\mathrm{T}_{8}$ : Positive control $+3 \mathrm{~g}$ Polyzyme $/ \mathrm{kg}$ diet.

${ }^{2}$ means \pm S.E. of 3 replicates/ treatment

${ }^{3} \mathrm{a}, \mathrm{b}, \mathrm{c} . \ldots \ldots \ldots$...etc: Means within the same column with different superscripts are significantly different $(\mathrm{P} \leq 0.05)$. 
Table 4: Effect of feeding White Morlar ducks on diets with low and normal crude protein content with different levels of Polyzyme on the performance index (\%) at 3 and 10 weeks of age and the European efficiency index (\%) at 10 weeks of age (Means \pm S. E).

\begin{tabular}{|c|c|c|c|}
\hline \multirow{2}{*}{ Dietary treatments $^{1}$} & \multicolumn{2}{|c|}{ Performance index } & European efficiency index $^{4}$ \\
\cline { 2 - 4 } & 3 weeks & 10 weeks & 10 weeks \\
\hline $\mathrm{T}_{1 \text { (Negative control) }}$ & $42.38^{\mathrm{d}} \pm 0.99$ & $117.89^{2,3 \mathrm{c}} \pm 2.46$ & 169.62 \\
\hline $\mathrm{T}_{2}$ & $47.85^{\mathrm{c}} \pm 1.20$ & $150.35^{\mathrm{b}} \pm 2.54$ & 217.74 \\
\hline $\mathrm{T}_{3}$ & $50.87^{\mathrm{bc}} \pm 1.17$ & $150.78^{\mathrm{b}} \pm 2.05$ & 217.14 \\
\hline $\mathrm{T}_{4}$ & $52.79^{\mathrm{ab}} \pm 1.49$ & $162.33^{\mathrm{a}} \pm 2.87$ & 233.22 \\
\hline $\mathrm{T}_{5 \text { (Positive control) }}$ & $54.71^{\mathrm{a}} \pm 1.04$ & $155.59^{\mathrm{ab}} \pm 5.24$ & 221.69 \\
\hline $\mathrm{T}_{6}$ & $49.64^{\mathrm{bc}} \pm 1.36$ & $153.87^{\mathrm{ab}} \pm 4.02$ & 220.11 \\
\hline $\mathrm{T}_{7}$ & $47.17^{\mathrm{c}} \pm 1.18$ & $151.64^{\mathrm{b}} \pm 3.64$ & 217.51 \\
\hline $\mathrm{T}_{8}$ & $47.34^{\mathrm{c}} \pm 1.28$ & $147.72^{\mathrm{b}} \pm 2.75$ & 212.70 \\
\hline Sig. & $*$ & $*$ & $*$ \\
\hline
\end{tabular}

${ }^{1} \mathrm{~T}_{1}$ : Negative control diet, $\mathrm{T}_{2}$ : Negative control $+1 \mathrm{~g}$ Polyzyme $/ \mathrm{kg}$ diet, $\mathrm{T}_{3}$ : Negative control $+2 \mathrm{~g}$ Polyzyme $/ \mathrm{kg}$ diet, $\mathrm{T}_{4}$ : Negative control $+3 \mathrm{~g}$ Polyzyme $/ \mathrm{kg}$ diet, $\mathrm{T}_{5}$ : Positive control diet, $\mathrm{T}_{6}$ : Positive control $+1 \mathrm{~g}$ Polyzyme / $\mathrm{kg}$ diet, $\mathrm{T}_{7}$ : Positive control $+2 \mathrm{~g}$ Polyzyme $/ \mathrm{kg}$ diet, $\mathrm{T}_{8}$ : Positive control $+3 \mathrm{~g}$ Polyzyme $/ \mathrm{kg}$ diet.

${ }^{2}$ means \pm S.E. of 3 replicates/ treatment.

3 a,b,c........etc: Means within the same column with different superscripts are significantly different $(\mathrm{P} \leq 0.05)$.

${ }^{4}$ European efficiency index, EEI $=($ Mean body weight, $\mathrm{kg} \times$ livability, $\%) /($ marketing age, days $\times$ feed conversion ratio) $\times 100$.

\section{Carcass traits:}

Results obtained in Table (5) showed the effect of Polyzyme supplementation on some carcass traits of White Molar ducks at 10 weeks of age. There were significant differences between all treatments on most observed carcass characteristics. Supplementation of 1, 2 and $3 \mathrm{~g}$ multi-enzyme/ Kg low crude protein diets $\left(\mathrm{T}_{2}, \mathrm{~T}_{3}\right.$ and $\left.\mathrm{T}_{4}\right)$ significantly $(\mathrm{P} \leq 0.05)$ increased empty carcass weight $(2910,2990$ and $3084 \mathrm{~g})$ compared to the negative control $\left(\mathrm{T}_{1}, 2485 \mathrm{~g}\right)$. Chicks fed un-supplemented positive control had increased carcass weight being 3006g which recorded the highest dressing percentage $(73.23 \%)$. Almost, dressing percentage was the same in all treatments fed low or normal crude protein diet supplemented with different levels of polyzyme except in chicks fed low crude protein diet without supplementation which recorded the lowest dressing percentages (71.86\%). Supplementation of $3 \mathrm{~g}$ multi-enzyme to low protein diets $\left(\mathrm{T}_{4}\right)$ significantly $(\mathrm{P} \leq 0.05)$ increased all carcass traits and gibiets weight $(\mathrm{g})$, which suggests that there was a positive response to increase calorie-protein ratio when multienzymes were supplemented and the improvement on most observed carcass traits were related with increased body size. Gizzard percentage was affected by the addition of polyzyme supplementation to the low crude protein diets but without significance. It's clear that inadequate $\mathrm{CP}$ consequently amino acid negatively influence the broiler carcass composition (dressing and giblets percentage) in comparison with the control and the negative control diet supplemented with exogenous enzymes $\left(\mathrm{T}_{2}, \mathrm{~T}_{3}\right.$ and $\left.\mathrm{T}_{4}\right)$. In general, it was noted that enzyme supplementation increased carcass yield Wang et al. (2005) and Goli and Shahryar (2015) in broiler chicks. Gitoee et al. (2015) showed that birds fed diets supplemented with $500 \mathrm{mg}$ Avizyme 1502, (combination of xylanase, $\alpha$-amaylase and protease)/ $\mathrm{Kg}$ had a significantly $(\mathrm{P} \leq 0.05)$ higher giblets weight and some carcass traits at 42 and 49 days. In contrast, our results are opposite to the results of Saleh et al. (2004), Zakaria et al. (2010) and Castro et al. (2019) who noted that alphaamylase supplementation did not influence carcass parameters. The same trend was noticed by Café et al. (2002) who reported that addition of commercial multi-enzymes to corn-soybean meal-based diets did not improve dressing percentage. 


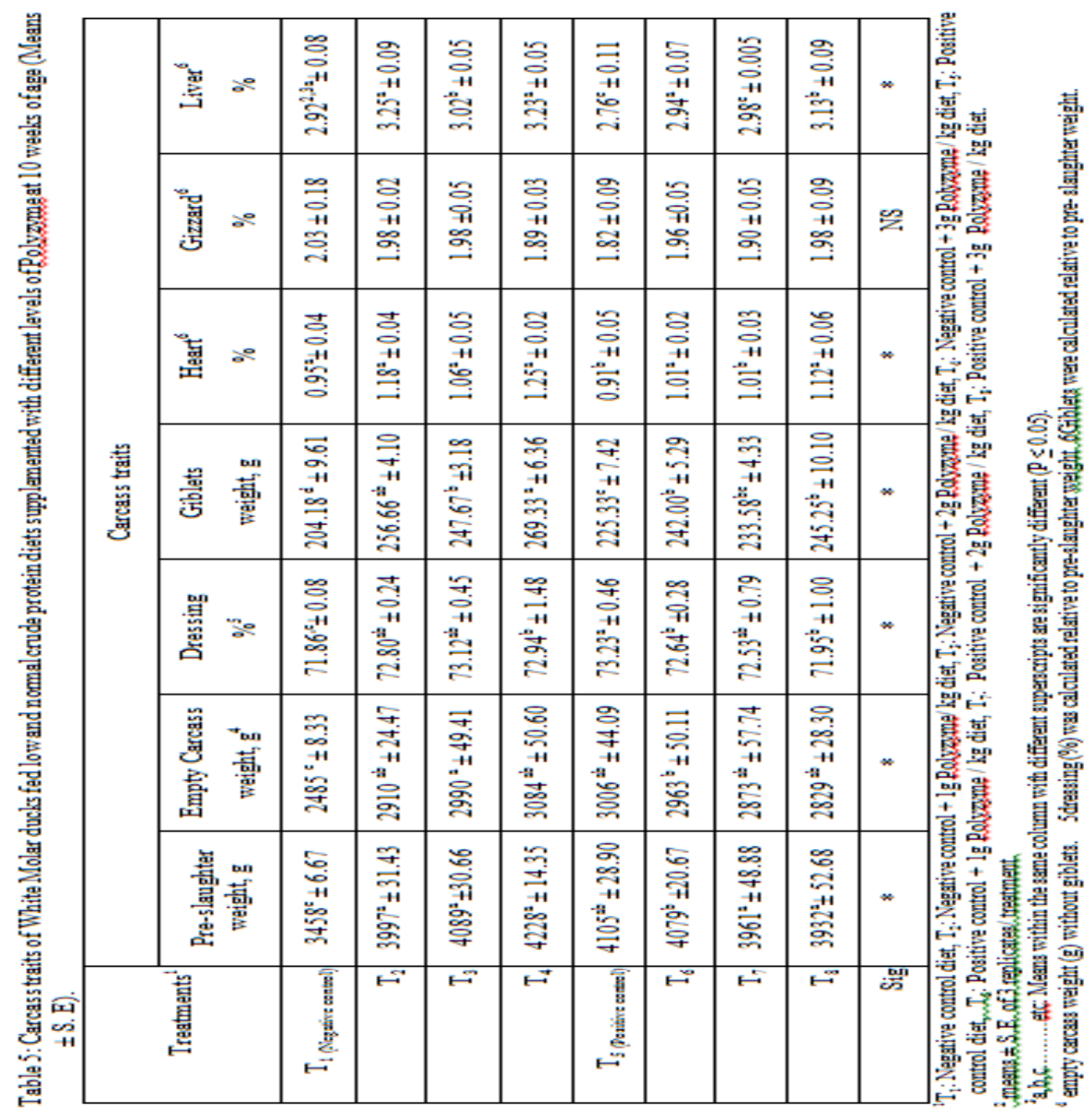




\section{Serum blood parameters:}

Data on some serum biochemical parameters of White Molar ducks are shown in Table (6). It's clearly that all groups fed diets supplemented with polyzyme had significantly varied effects on some blood biochemical parameters. Chicks fed low crude protein diet supplemented with 2 and 3 $\mathrm{g}$ Polyzyme/ $\mathrm{Kg}$ diet had significantly increased total protein and it may be equal to its value in the positive control group $\left(\mathrm{T}_{5}\right)$; being 3, 2.85 and $3.06 \mathrm{~g} / \mathrm{dl}$, respectively. Albumen and createnine had significantly varied effects by the supplementation but almost were reduced with the addition of polyzyme, while an opposite trend was observed in blood glucose and total lipids. Enzymes supplementation to the positive control group $\left(\mathrm{T}_{7}\right)$ had significantly $(\mathrm{P} \leq 0.05)$ reduced blood total lipids, cholesterol and triglyceides being (391.00, 125.67 and $105.33 \mathrm{mg} /$ dl) in comparison with the negative control $\left(\mathrm{T}_{1}\right.$, 442.06, 142.17 and $118.30 \mathrm{mg} / \mathrm{dl}$, respectively and positive control, $\mathrm{T}_{5}(450.90,155.00$ and $129.67 \mathrm{mg} / \mathrm{dI})$ at 10 weeks of age. While, ALT concentrations was not significantly affected compared to chicks fed diets without multienzymes supplementation. These results are in agreement with Abdel-Hafeez et al. (2017) who reported that dietary enzyme supplementation significantly decreased total cholesterol concentration of blood broiler chicks. Hajati et al. (2009) reported that enzyme inclusion increased the concentration of blood total cholesterol at 10, 28 and $42 \mathrm{~d}$ of age, $(\mathrm{P} \leq 0.05)$ of broiler chicks.

\section{Intestinal morphological parameters:}

Means of different morphological sections of Molar ducks small intestine are presented in Table (7) and illustrated in Figures (1-8). The highest villi height in duodenum were observed in groups fed the positive control diet without polyzyme $\left(\mathrm{T}_{5}, 1779 \mu \mathrm{m}\right)$ and in chicks fed the negative control diet supplemented with $3 \mathrm{~g}$ polyzyme, $\left(\mathrm{T}_{4}\right)$ being $1726 \mu \mathrm{m}$. The same trend was noticed in jejunum and ileum height (Caspary, 1992). The best ileum villi height: width ratio was noticed in chicks fed the positive control diet without polyzyme $\left(\mathrm{T}_{5}, 17.95 \mu \mathrm{m}\right)$ in comparison with the other supplemented and unsupplemented group. It's understood that greater villus height is an indicator that the function of intestinal villi is activated (Yasar and Forbes, 2000 and Shamoto and Yamanchi, 2000).

Increasing the villus height suggests an increased surface area capable of greater absorption of available nutrients by the enzyme supplementation. These results are in a harmony with the results of Puangkhum et al. (2019) who showed that multi-enzyme supplementation had higher small intestinal morphology (villus height, crypt depth and villus height/ crypt depth ratio) of ducks at 45 days of age. Sharifi et al. (2013) showed that Natuzyme-supplemented diets consuming wheat or wheat and canola meal led to significant increase of villi height and the ratio between villus heights: crypt depth in the small intestine.

\section{Economic efficiency:}

Data pertaining to dietary low crude protein with or without Polyzyme of different levels supplementation on economical and relative economic efficiency are presented in Table (8). In comparison with the positive control, $\mathrm{T}_{5}$ $(100 \%)$, the supplementation of Polyzyme improved economical and relative economic efficiency $\left(\mathrm{T}_{2}\right) ; 110.64$ negative control with $1 \mathrm{~g}$ multi-enzyme/ $\mathrm{Kg}$ diets. While the lowest of economical and relative economic efficiency being (1.25 and 88.65) in the negative control $\left(\mathrm{T}_{1}\right)$ though our inputs and outcomes for 10 weeks White Molar ducks.This results harmony with Selim et al. (2016) and Behera et al. (2016) noted that addition of enzyme to low protein reduced the feeding GST/ $\mathrm{Kg}$ of live body weight. 
A. M. H. Abou-Ashour, et al.,

\begin{tabular}{|c|c|c|c|c|c|c|c|c|c|c|c|}
\hline 寻 & \multirow{2}{*}{ 官 } & 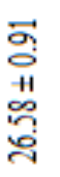 & 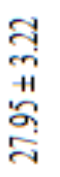 & 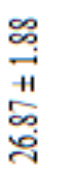 & 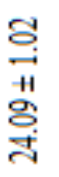 & 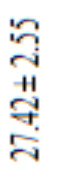 & 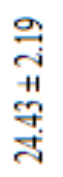 & 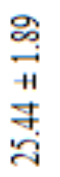 & 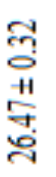 & 告 & \multirow{3}{*}{ 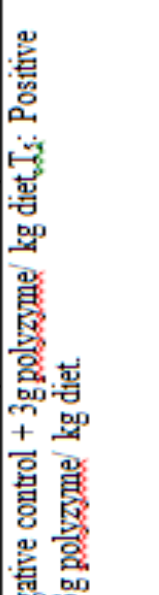 } \\
\hline 点 & & 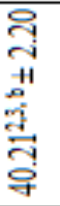 & $\begin{array}{l}\text { 号 } \\
\text { Ḧ } \\
\text { 总 } \\
\text { gू }\end{array}$ & 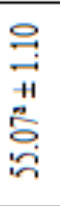 & 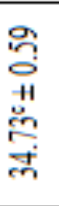 & 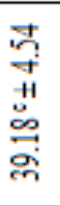 & 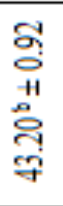 & 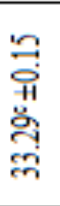 & 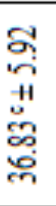 & * & \\
\hline 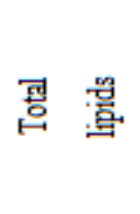 & \multirow{3}{*}{ 嶉 } & 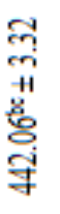 & 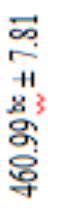 & 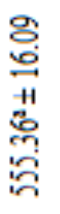 & 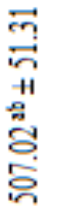 & 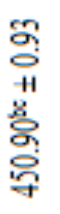 & $\begin{array}{l}\text { क } \\
\text { 華 } \\
\text { 今. } \\
\text { 。 } \\
\text { 守 }\end{array}$ & 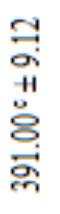 & 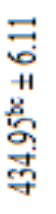 & * & \\
\hline 汇憘 & & 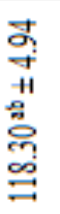 & 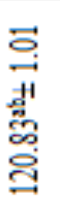 & $\begin{array}{l}8 \\
0 \\
\text { o } \\
+1 \\
8 \\
8 \\
0 \\
0\end{array}$ & 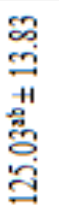 & 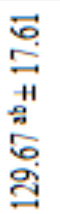 & 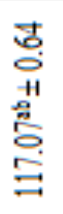 & 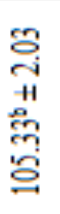 & 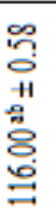 & * & \multirow{4}{*}{ 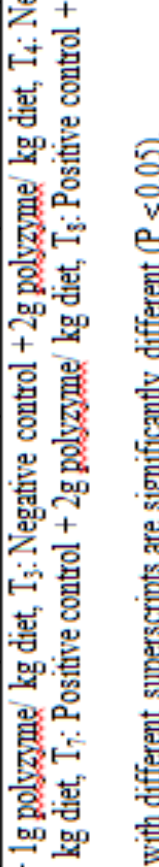 } \\
\hline $\begin{array}{l}\text { 岕 } \\
\text { 苛 }\end{array}$ & & $\begin{array}{l}\vec{b} \\
0 \\
\text { +1 } \\
\stackrel{8}{0} \\
\text { 응 }\end{array}$ & 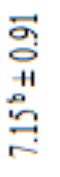 & 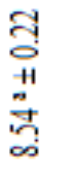 & $\begin{array}{l}\text { ơ } \\
0 \\
\text { +1 } \\
\text { \& } \\
\text { ô } \\
\text { r }\end{array}$ & 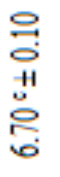 & 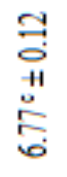 & 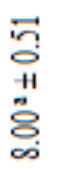 & $\begin{array}{l}\text { J } \\
\text { o } \\
\text { H } \\
\text { o } \\
\infty \\
\text { o. }\end{array}$ & * & \\
\hline 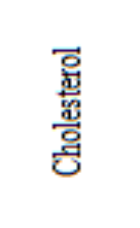 & \multirow[t]{2}{*}{ 樂 } & 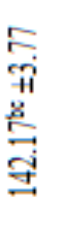 & 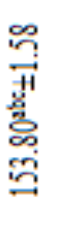 & 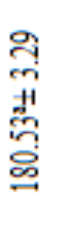 & 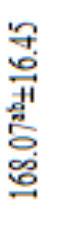 & 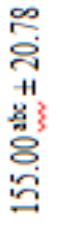 & 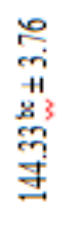 & 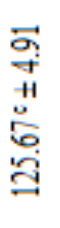 & 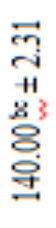 & * & \\
\hline 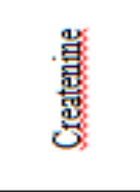 & & 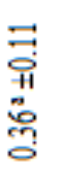 & 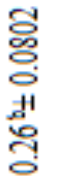 & 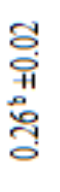 & 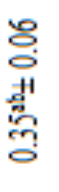 & 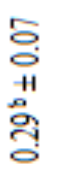 & 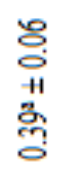 & 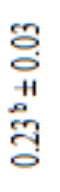 & 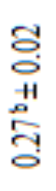 & * & \\
\hline $\begin{array}{l}\text { 貣 } \\
\text { 堂 }\end{array}$ & \multirow[t]{2}{*}{$\frac{d}{m}$} & 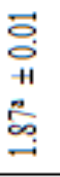 & 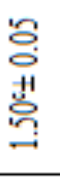 & 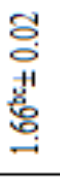 & 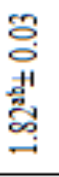 & $\begin{array}{l}\text { 공 } \\
\text { 总 } \\
\text { 은 }\end{array}$ & 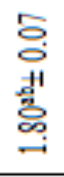 & $\begin{array}{l}8 \\
8 \\
0 \\
\text { 艹⿱艹口 } \\
\text { 은 }\end{array}$ & 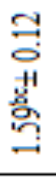 & * & 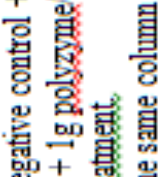 \\
\hline $\begin{array}{l}\text { 荘 } \\
\text { 总 } \\
\text { 동 } \\
\text { ․ }\end{array}$ & & 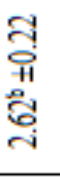 & 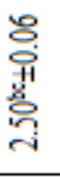 & 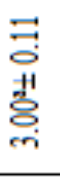 & 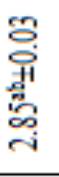 & 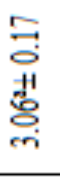 & 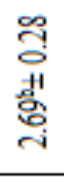 & 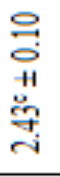 & 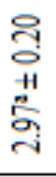 & $*$ & 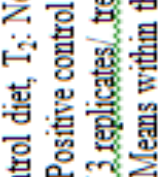 \\
\hline & & 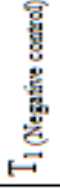 & 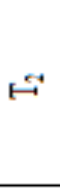 & $\stackrel{\varpi}{\oplus}$ & $\stackrel{+}{\bullet}$ & 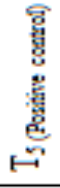 & $\stackrel{\bullet}{\bullet}$ & $\stackrel{F}{F}$ & 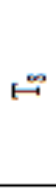 & 咢 & 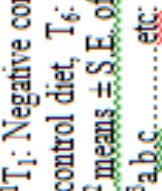 \\
\hline
\end{tabular}




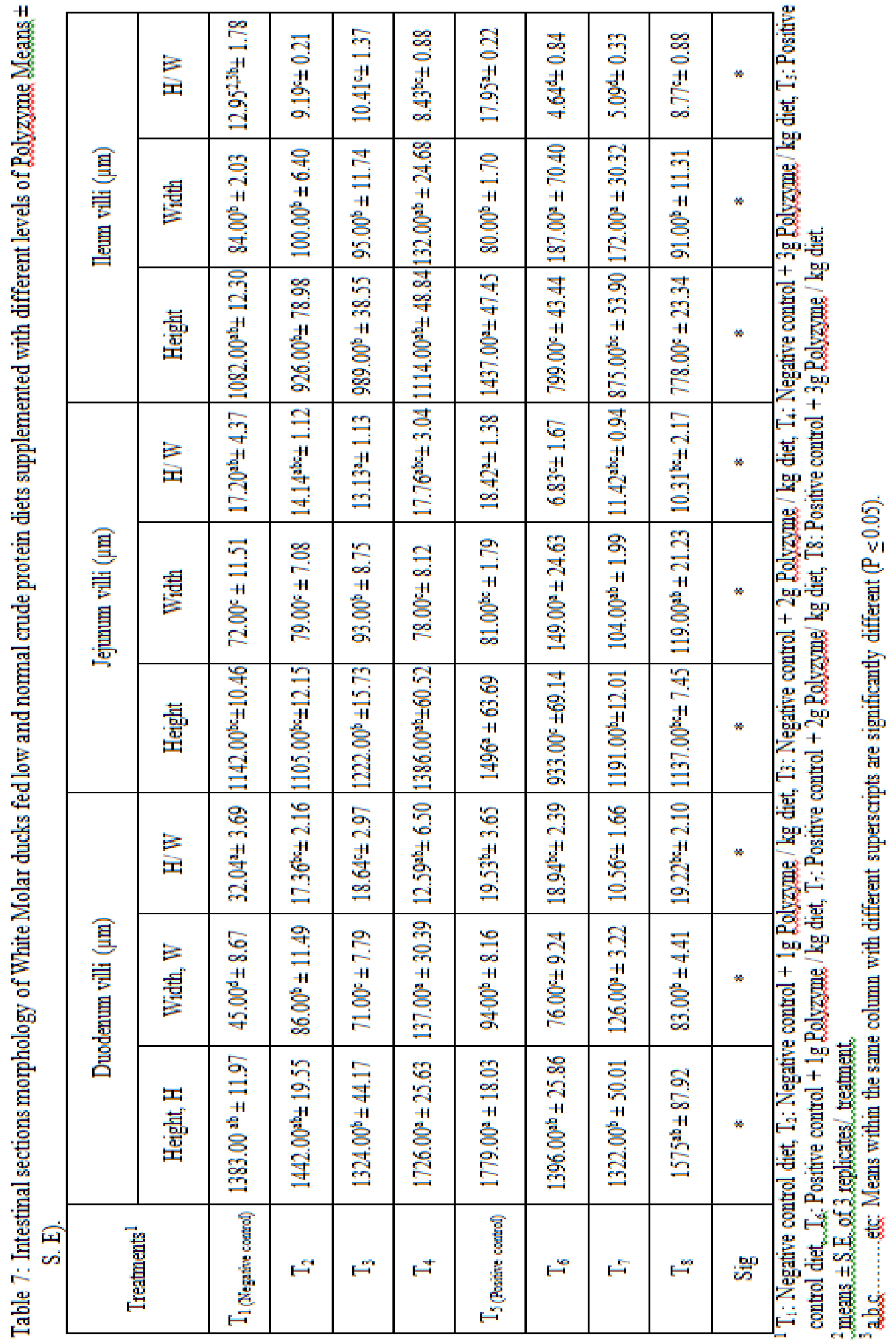




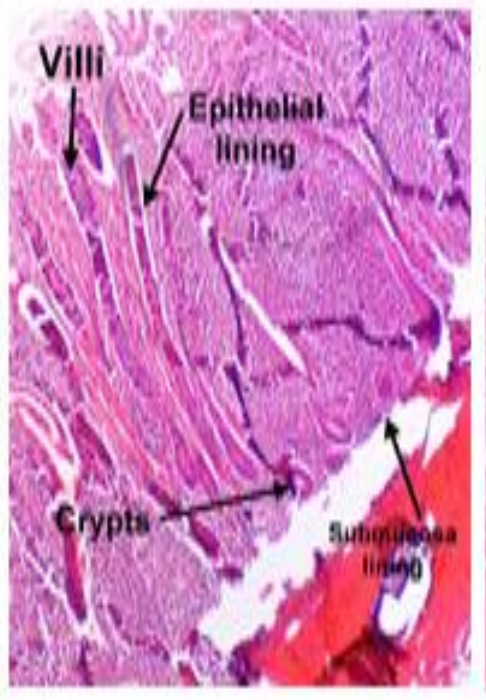

duodenum

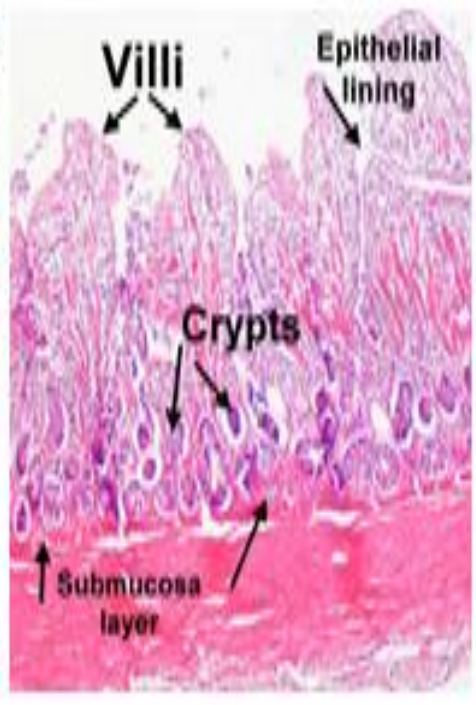

Iginum

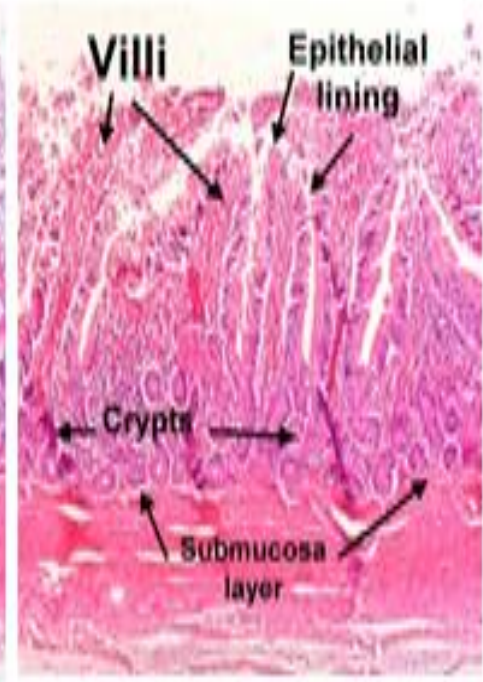

ileum

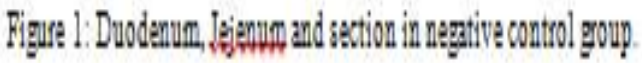

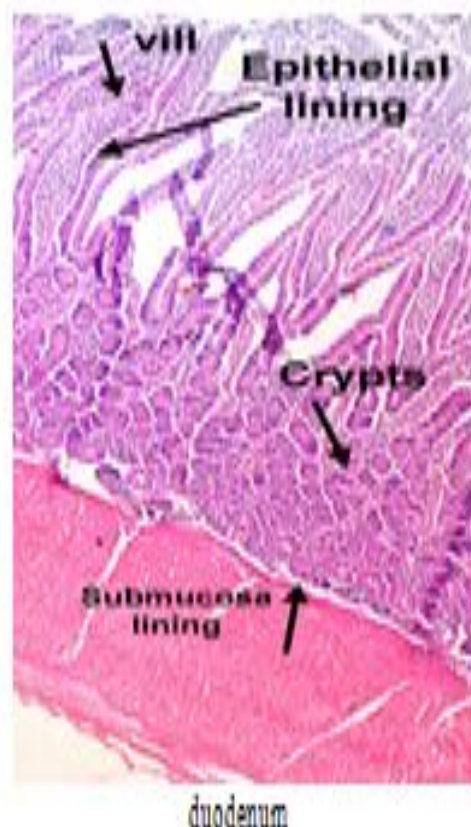

duodenum
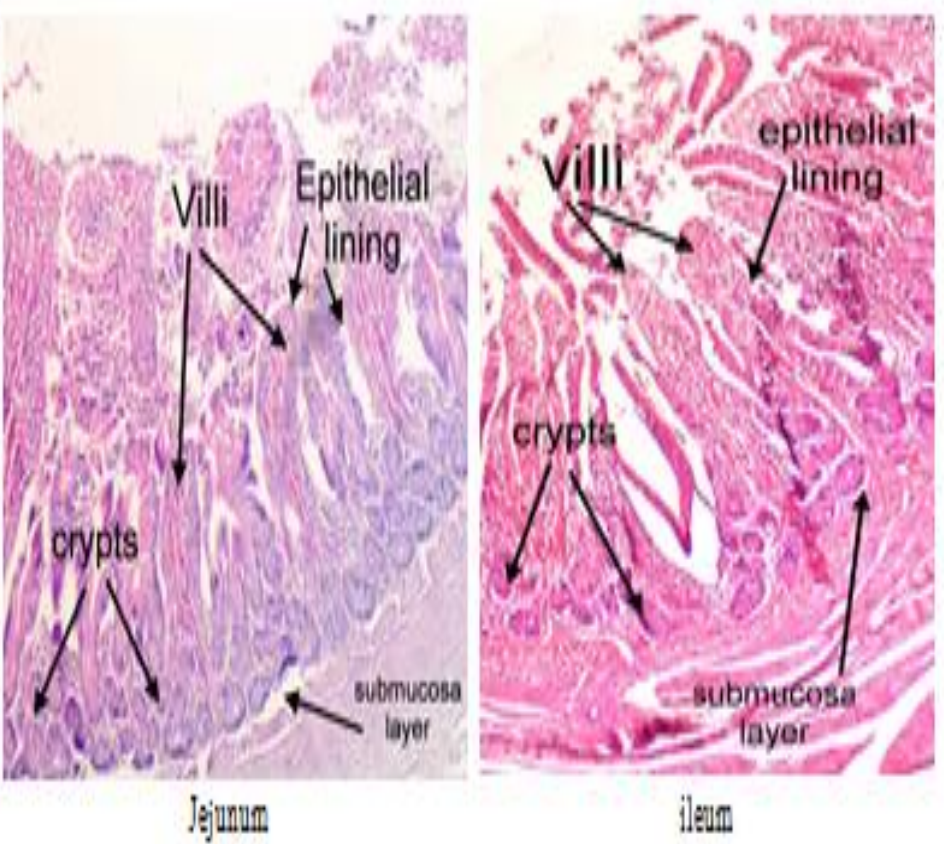

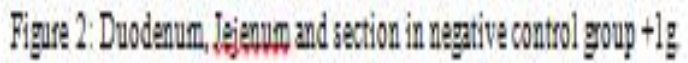




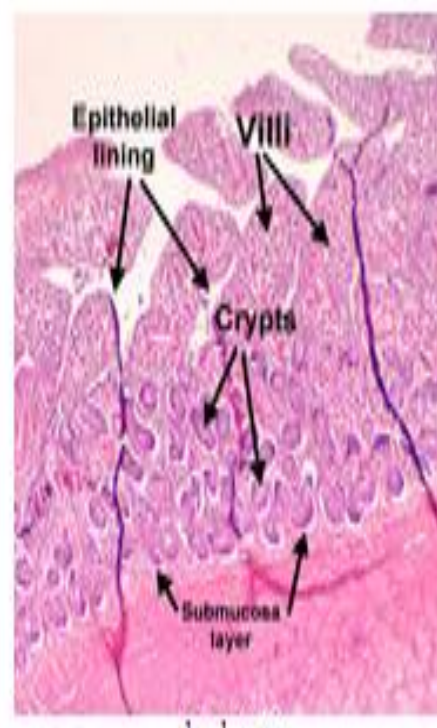

duodenum

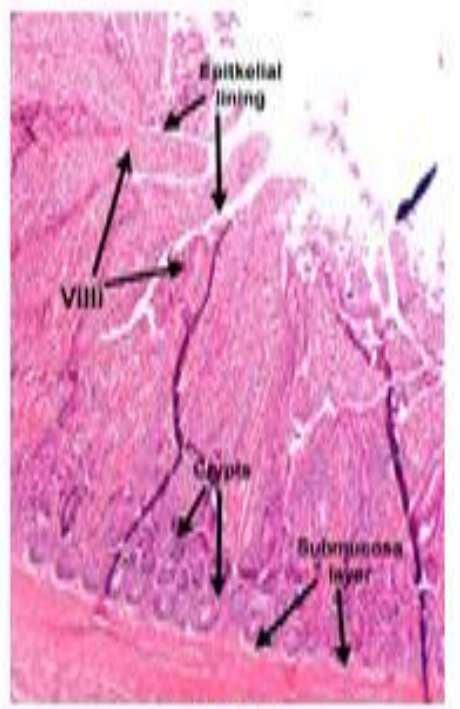

Jefunum

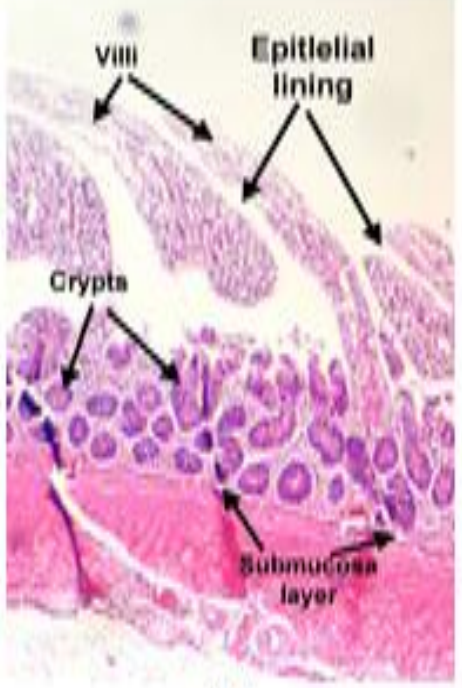

ileum

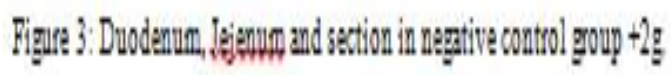

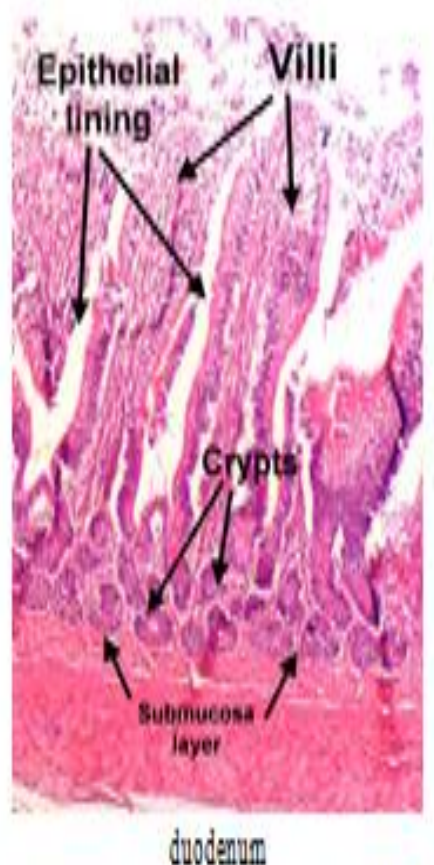

duodenum
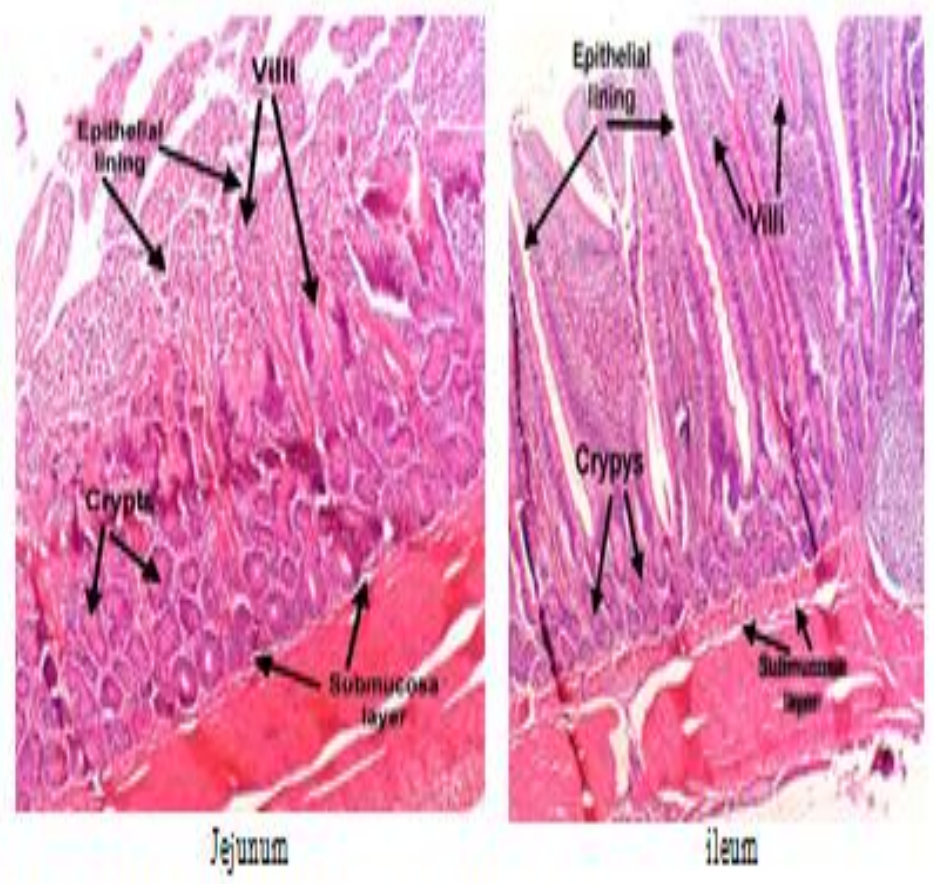

ileum

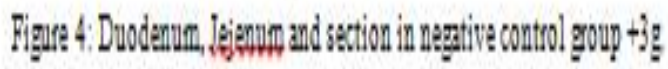



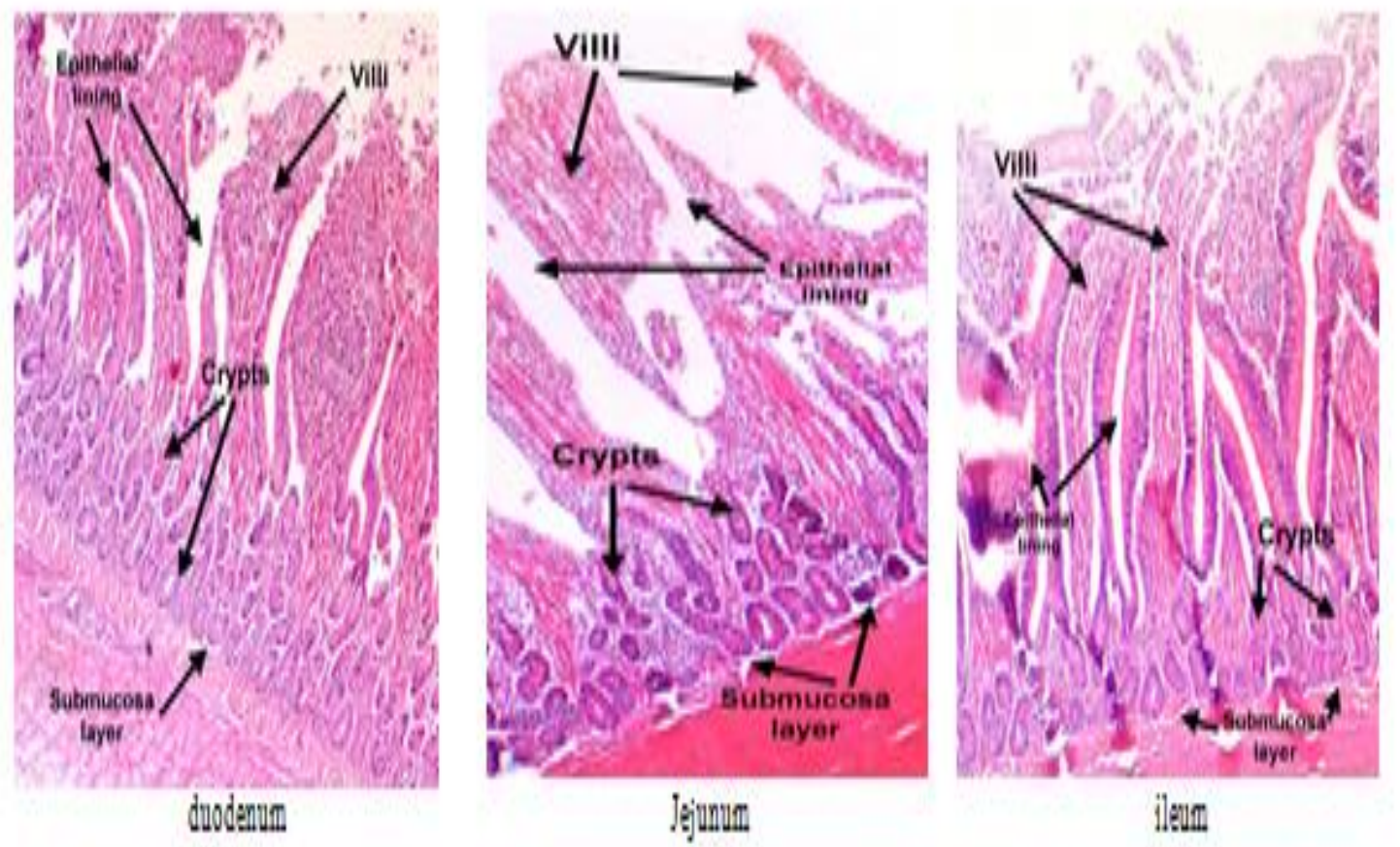

Figur S: Dudenum, dignom and section in positive control goup.
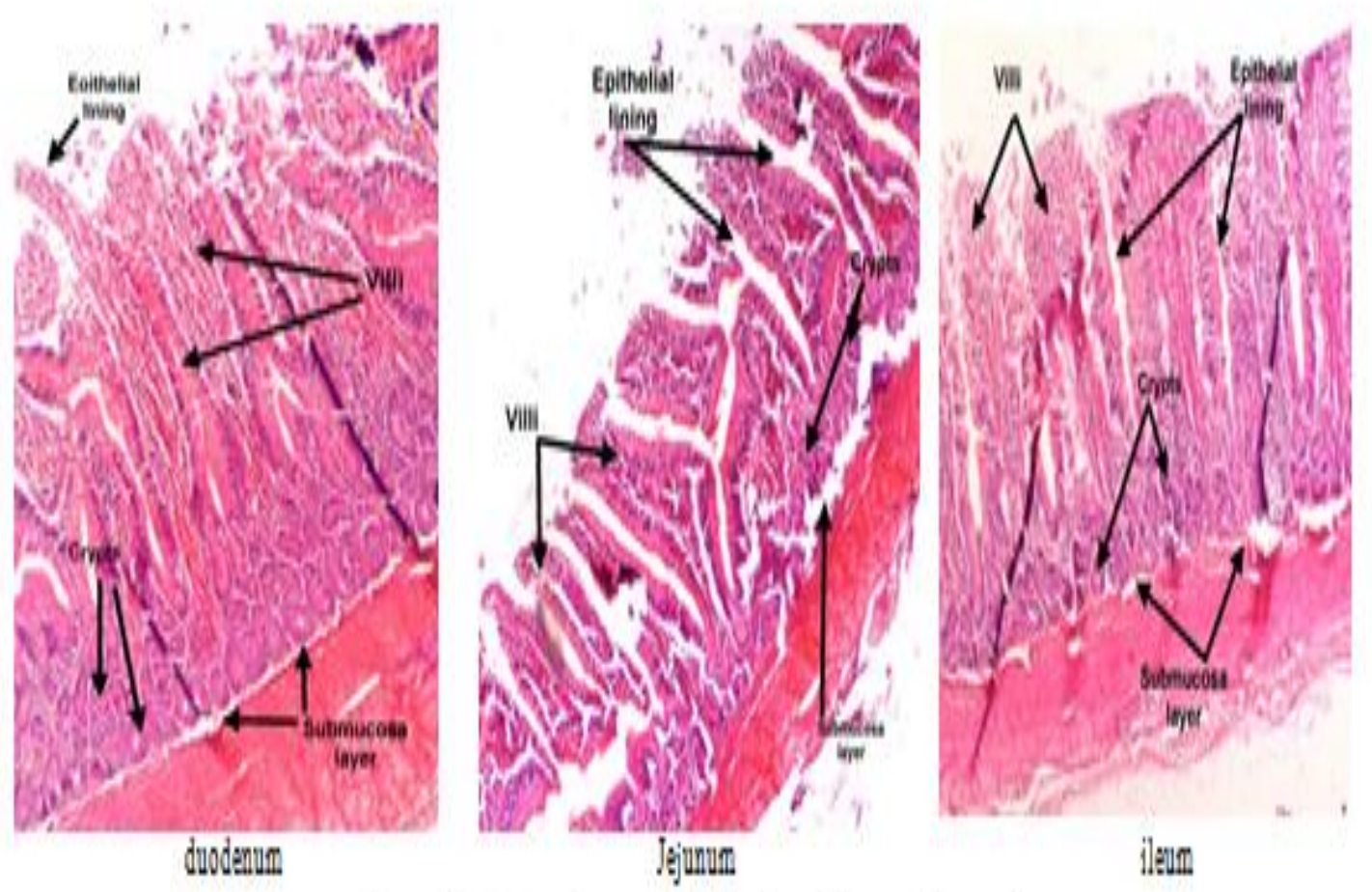

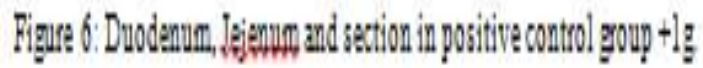




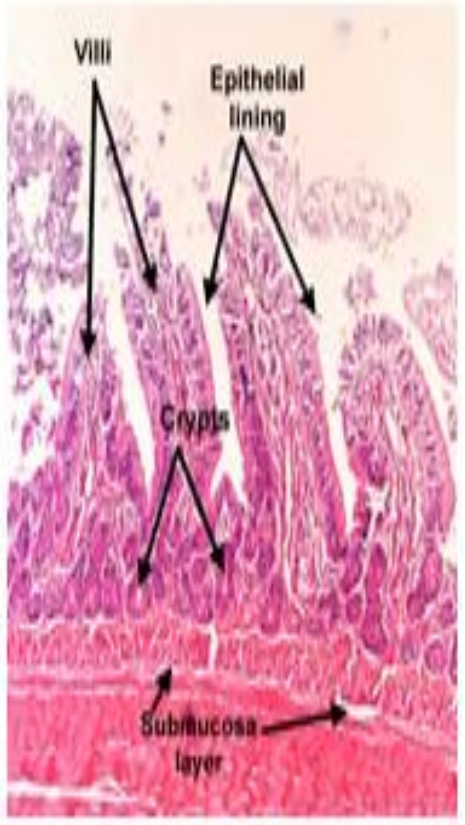

duodenum

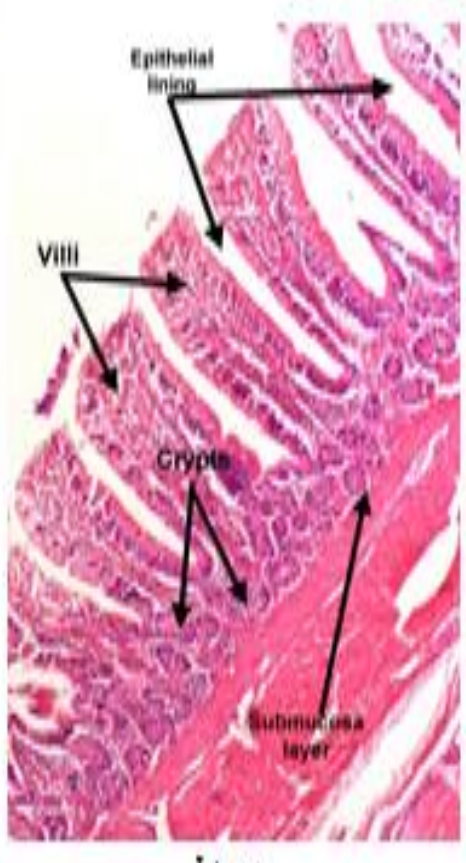

Jefunum

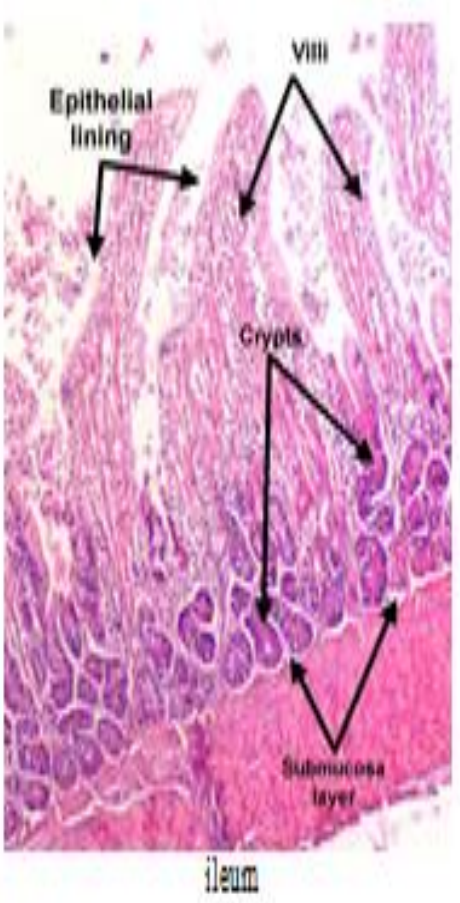

ileum

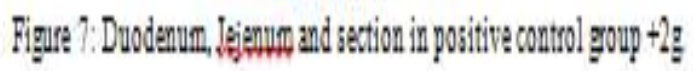

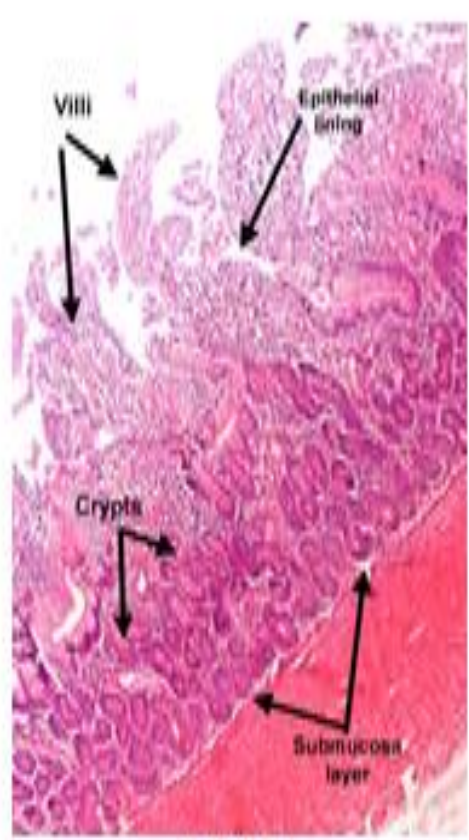

duodenum

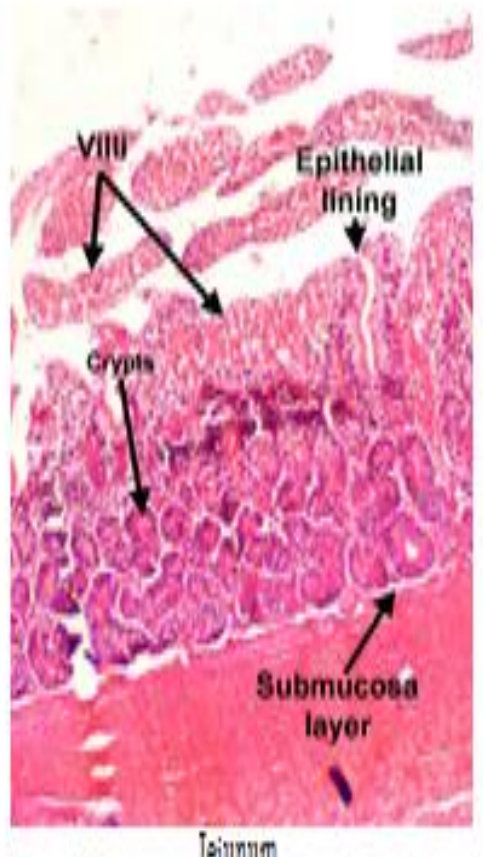

Jefunam

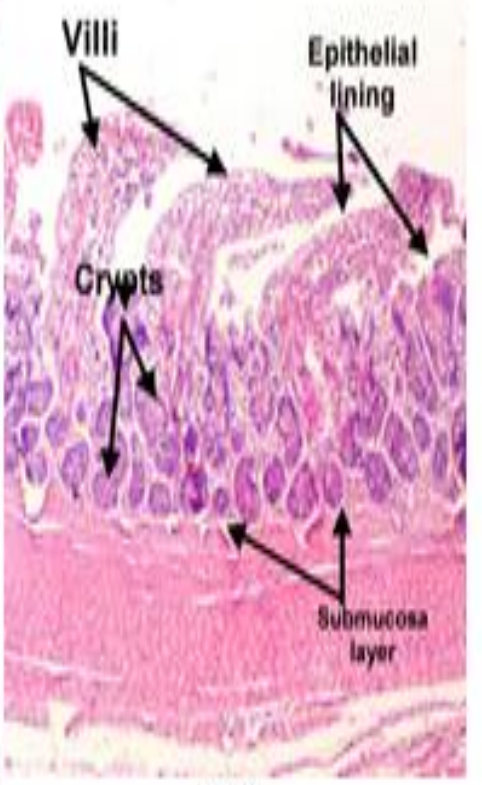

ileur

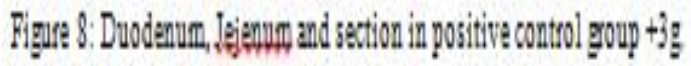


Table 8. Economic efficiency of White Molar ducks fed low crude and normal protein diets supplemented with different levels of Polyzyme at 70 days of age.

\begin{tabular}{|l|c|c|c|c|c|c|c|c|}
\hline \multirow{2}{*}{ Items } & \multicolumn{7}{c|}{ Dietary treatments } \\
\cline { 2 - 9 } & $\mathrm{T}_{1}$ & $\mathrm{~T}_{2}$ & $\mathrm{~T}_{3}$ & $\mathrm{~T}_{4}$ & $\mathrm{~T}_{5}$ & $\mathrm{~T}_{6}$ & $\mathrm{~T}_{7}$ & $\mathrm{~T}_{8}$ \\
\hline Initial body weight, g. & 47.70 & 47.60 & 47.63 & 47.63 & 47.73 & 47.80 & 47.70 & 47.77 \\
\hline Final body weight, kg. & 3.55 & 4.10 & 4.18 & 4.31 & 4.19 & 4.16 & 4.05 & 4.02 \\
\hline Body weight gain, kg. & 3.50 & 4.05 & 4.13 & 4.26 & 4.14 & 4.11 & 4.00 & 3.97 \\
\hline Total revenue ${ }^{2}, \mathrm{L.}$ E. & 133 & 154 & 157 & 162 & 157 & 156 & 152 & 151 \\
\hline Feed intake, kg. & 10.41 & 10.38 & 11.35 & 11.23 & 11.12 & 11.07 & 10.59 & 10.68 \\
\hline Price of one kg feed, L. E. & 5.67 & 5.80 & 5.92 & 6.05 & 5.85 & 5.98 & 6.10 & 6.23 \\
\hline Feed cost, L. E. & 59.00 & 60.20 & 67.19 & 67.94 & 65.10 & 66.20 & 64.60 & 66.54 \\
\hline Net revenue $^{3}$, L. E. & 74.00 & 93.80 & 89.81 & 94.06 & 91.90 & 89.80 & 87.40 & 84.46 \\
\hline Economical efficiency $^{4}$. & 1.25 & 1.56 & 1.34 & 1.38 & 1.41 & 1.36 & 1.35 & 1.27 \\
\hline Relative economic efficiency, \%. $^{*} 88.65$ & 110.64 & 95.04 & 97.87 & 100 & 96.50 & 95.70 & 90.10 \\
\hline
\end{tabular}

${ }^{1} \mathrm{~T}_{1}$ : Negative control diet, $\mathrm{T}_{2}$ : Negative control $+1 \mathrm{~g}$ Polyzyme $/ \mathrm{kg}$ diet, $\mathrm{T}_{3}$ : Negative control $+2 \mathrm{~g}$ Polyzyme $/ \mathrm{kg}$ diet, $\mathrm{T}_{4}$ : Negative control $+3 \mathrm{~g}$ Polyzyme $/ \mathrm{kg}$ diet, $\mathrm{T}_{5}$ : Positive control diet, $\mathrm{T}_{6}$ : Positive control $+1 \mathrm{~g}$ Polyzyme $/ \mathrm{kg}$ diet, $\mathrm{T}_{7}$ : Positive control $+2 \mathrm{~g}$ Polyzyme $/ \mathrm{kg}$ diet, $\mathrm{T}_{8}$ : Positive control $+3 \mathrm{~g}$ Polyzyme $/ \mathrm{kg}$ diet.

Price of one $\mathrm{kg}$ live body weight was 38 L.E. Price of one $\mathrm{kg}$ multi enzymes was $125 \mathrm{~L} . \mathrm{E}$.

${ }^{2}$ Total revenue $=$ live body weight gain $\times$ marketing price.

${ }^{3}$ Net revenue $=$ Total revenue - Feed cost. $\quad{ }^{4}$ Economical efficiency $=$ Net revenue $/$ Feed cost.

\section{Conclusion:}

In general, and through the results obtained from feeding White Molar duck chicks from one day to 10 weeks of age on low crude protien diets (18 and 16\%) during the starter period (1 $21 \mathrm{~d})$ and the finisher $(22-70 \mathrm{~d})$ with addition of different levels of commercial Polyzyme mixture (1, 2 and $3 \mathrm{~g} / \mathrm{Kg}$ diet) improved growth performance due to increased activity of the small intestine and rate of nutrient absorption. The european efficiency ratio and performance index were improved when adding $3 \mathrm{~g}$ Polyzyme $\mathrm{Kg}$ diet $\left(4^{\text {th }}\right.$ treatment), while the economic and relative efficiency were better (1.56 and 110.64 , respectively) in the $2^{\text {nd }}$ treatment in which chicks fed low crude protein diet $+1 \mathrm{~g}$ Polyzyme compared to the other trearments.

\section{REFERANCES}

Abdel-Hafeez, H. M.; E. S. E. Saleh; S. S. Tawfeek; I. M. I. Youssef and A. S. A. Abdel-Daim (2017). Effects of probiotic, prebiotic, and synbiotic with and without feed restriction on performance, hematological indices and carcass characteristics of broiler chickens. Asian - Australas. Journal. Animal. Science, 30 (5): 672 - 682.

Al-Khalifah, H. S. (2018). Benefits of probiotics and/ or prebiotics for antibiotic-reduced poultry. Poultry. Science, 97: 3807 - 3815.

Alam, M. J.; M. A. R. Howlider; M. A. H. Pramanik and M. A. Haque (2003). Effect of exogenous enzyme in diet on broiler performance. International Journal of Poultry Science., 2: 168 - 173.

Al-Harthi, M. A.; Y. A. Attia; A. S. El - Shafey and M. F. Elgandy (2020). Impact of phytase on improving the utilisation of pelleted broiler diets containing olive by-products. Italian Journal of Animal Science, 19 (1): 310 $-318$.

Bedford, M. R. and A. J. Morgan (1996). The use of enzymes in poultry diets. World's Poultry Science Journal, 52: 61-68.

Behera, N. K; L. K. Bahu; S. K. Sahoo; S. C. Giri; P. C. Pati; B. Pangrahi and S. K. Joshi (2016). Effect of feeding different levels of 
protein on mortality, carcass characteristics, biochemical parameter, time motion study and economics of desi duck under intensive system of rearing. Asian of Animal Sciences, 10 (1): $106-112$.

Cafe', M. B.; C. A. Borges; C. A. Fritts and P. W. Waldroup (2002). Avizyme improves performance of broilers fed corn-soybean meal-based diets. Applied Poultry Research. 11: $29-33$.

Caspary, W. F (1992). Physiology and pathophysiology of intestinal absorption. The American Journal of Clinical Nutrition, 55: $299 \mathrm{~S}-308 \mathrm{~S}$.

Castro, S. F.; G. B. Antônio; M. C. L. Eduardo; H. S. C. Alisson; G. G. F. Verônica and C. C. C. Julio (2019). Effect of different levels of supplementary alpha-amylase in finishing broilers. Animal Sciences, V. 42, e47546.

Cowieson, A. J and F. F. Roos (2016). Toward optimal value creation through the application of exogenous mono-component protease in the diets of non-ruminants. Animal Feed Science, 221: 331 - 340.

Dongare, N.A.; A.D. Deshmukh; A.P. Dhok; S.R. Lende and P.E. Taksande (2017). Supplementation of Protease and Xylanase Enzymes in Broiler Diet with Varying Energy and Protein Levels. International Journal Curr. Microbiol Applied Science, 6 (11): 1715-1720.

Duncan, D. B. (1955). Multiple range and multiple F tests. Biometrics, 11:1- 42.

Geyra, A.; Z. Uni and D. Sklan (2001). Enterocyte dynamics and mucosal development in the post hatch chick. Poultry Science, 80, 776 - 782 .

Giacobbo, F. C. N.; C. Eyng.; R. V. Nunes.; C. Souza.; L. V. Teixeira.; R. Pilla.; J. S. Sunchodolski and C. Bortoluzzi (2021). Influence of enzyme supplementation in the Diets of Broiler chickens formulated with different corn hybrids dried at various temperatures. Animals, 11, 643.
Gitoee, A.; H. Janmohammadi; A. Taghizadeh and S. A. Rafat (2015). Effects of a multienzyme on performance and carcass characteristics of broiler chickens fed cornsoybean meal basal diets with different metabolizable energy levels. Journal of Applied Animal Research, 43 (3): 295 - 302.

Goli, S. and H. Aghdam Shahryar (2015). Effect of enzymes supplementation (Rovabio and Kemin) on some blood biochemical parameters, performance and carcass characterizes in broiler chickens. Iranian Journal of Applied Animal Science, 5 (1): 127-131.

Hajati, H.; M. Rezaei and H. Sayyahzadeh (2009). The effects of enzyme supplementation on performance, carcass characteristics and some blood parameters of broilers fed on corn-soybean meal-wheat diets. International Journal of Poultry Science, 8 (12): 1199 - 1205.

Heady, E. O. and H. R. Jensen (1954). Farm management economics. Pentice- Hall Inc. Englewood Cliffs, N.J., USA.

Jamroz, D.; K. Eder; A. Wiliczkiewicz and M. Kirchgessner (1998). Digestibility of NSPbound sugars in feeding triticale and enzymes to chickens, ducks and geese. Journal of Animal Physiol Animal. Nutrition, 79: 113122.

Kobayashi, H.; K, Nakashima; A. Ishida; A. Ashihara and M. Katsumata (2013). Effects of low protein diet and low protein diet supplemented with synthetic essential amino acids on meat quality of broiler chickens. Journal Animal Science, 84:489 - 495.

Kocher, A.; M. Choct; M. D. Porter and J. Broz (2002). Effect of feed enzymes on nutritive value of soybean meal fed to broilers. Brazilian Poultry Science, 43: 54-63.

Law, F. L.; Z. Idrus; A. S. Farjam, L. J. Boo and E. A. Awad (2019). Effects of protease supplementation of low protein and/or energy diets on growth performance and blood 
parameters in broiler chickens under heat stress condition. Italian Journal of Animal Science, 1: 679 - 689.

Lazaro, R.; M. Garcia; P. Medel and G. G. Mateos (2003). Influence of enzymes on performance and digestive parameters of broilers fed rye-based diets. Poultry Science, 82: 132 - 140.

Mahmood, T; M. Mirza and H. Nawaz (2017). Effect of supplementing exogenous protease in low protein by-product meal based diets on growth performance and nutrient digestibility in broilers. Animal Feed Science, 228: $23-$ 31.

Metwally, M. A.; M. F. A. Farghly; Z. S. H. Ismail; M.E. Ghonime and I. Mohamed (2020). Effect of different levels of optizyme and phytase enzyme and their interactions on the performance of broiler chickens fed cornsoybean meal: 2.tibia characteristics and calcium and phosphorus retention efficiency. Egyptian Journal Nutrition and Feeds, 23 (1): 151-160.

Ndazigaruye, G.; K. Da-Hye; K. Chang - Won; K. Kyung-Rae; J. Yong-Jin; L. Sang-Rak and L. Kyung-Woo (2019). Effects of lowcprotein diets and exogenous protease on growth performance, carcass traits, intestinal morphology, cecal volatile fatty acids and serum parameters in broilers. Animals, 226.

North, M. O. (1981). Commercial chicken production manual. $3^{\text {rd }}$ Ed., The AVI, Publishing Co. Inc., West-port, Connecticut, U. S. A.

Noy, Y. and D. Sklan (1995). Digestion and absorption in the toung chick. Poultry Science, 74: 366 - 373 .

NRC (1994). Nutrient requirements of poultry. $9^{\text {th }}$ rev. ed. Washington (DC) National Academy Press.

Puangkhum, C.; C. Rakangthong; T. Poeikhampha; K. Poungpong and C. Bunchasak (2019). Effect of supplemental multi-enzymes in the diet of meat-type ducks on production performance, carcass yields and gastrointestinal morphology. Internation Journal of Poultry Science: 18 (12): 648 655.

Saleh, F.; A. Ohtsuka; T. Tanaka and K. Hayashi (2004). Carbohydrases are digested by proteases present in enzyme preparations during in vitro digestion. Journal Poultry Science, 41: 229 - 235.

Selim, N. A.; H. H. Habib; H. A. Abdel Magied; A. H. Waly; A.A. Fadl, and S.M. Shalash (2016). Evaluation of using protease enzyme at different levels of protein in corn soybean meal broiler diets. Egyptation Poultry Science, 36 (I): 231 - 247.

Shamoto, K. and K. Yamauchi (2000). Recovery Responses of Chick Intestinal Villus Morphology to Different Refeeding Procedures. Poultry Science, 79: 718 - 723.

Sharifi, S. D.; G. Golestani; A. Yaghobfar; A. Khadem and H. Pashazanussi (2013). Effects of supplementing a multi enzyme to broiler diets containing a high level of wheat or canola meal on intestinal morphology and performance of chicks. Journal Applied Poultry Research, 22: 671- 679.

Shirmohammad, F. and M. Mehri (2011). Effects of dietary supplementation of multi-enzyme complex on the energy utilization in rooster and performance of broiler chicks. Afrrican Journal Biotechnol, 10: 7541 - 7547.

Snedecor, W. G. and G. W. Cochran (1982). Statistical methods. (6 ${ }^{\text {th }}$ ed.). iowa State College Press. Iowa, USA.

Soltan, M. E. and Z. Kusainova (2012). Performance of broiler chickens in different farming with different feed conversion under Egyptian conditions. Minufiya Journal Agriculture Research, 37 No. (1): 1155 1159.

SPSS (2011). SPSS 11.0 for Windows. SPSS Inc., Chicago. Standardization ministration of china. 2005. National feed Industry Standards for Enzyme Assays in china. 
Teymouri, M and A. Hassanabadi (2021). Influence of corn conditioning temperature and enzyme supplementation on growth performance, nutrient utilisation and intestine morphology of broilers fed mash corn-soy diets, Italian Journal of Animal Science, 20(1): 1015-1028.

Uni, Z.; Y. Noy and D. Sklan (1995). Postahatch changes in morphology and function of the small intestines in heavy-and lighy-strain chicks. Poultry Science, 74: 1622 - 1629.

Vukic-Vranjes, M. and C. Wenk (1995). Influence of dietary enzyme complex on the performance of broilers fed on diets with and without antibiotic supplementation. Brazilian Poultry Science, 36, $265-275$.

Wang, Z. R.; S. Y. Qiao; Q. Lu and D. F. Li (2005). Effects of enzyme supplementation on performance, nutrient digestibility, gastrointestinal morphology, and volatile fatty acid profiles in the hindgut of broiler fed wheat-based diets. Poultry Science, 84: 875 881.

Yasar, S and J. M. Forbes (2000). Enzyme supplementation of dry and wet wheat-based feeds for broiler chickens: performance and gut responses. Britch Journal Nutrition 84: $297-307$.

Zakaria, H. A. H.; A.R. J. Mohammad and A. A. I. Majdi (2010). The influence of supplemental multi-enzyme feed additive on the performance, carcass characteristics and meat quality traits of broiler chickens. International Journal of Poultry Science, 9 (2): $126-133$.

Zhan, X. A., M. Wang, H. Ren, R. Q. Zhao, J. X. Li, and Z. L. Tan (2007). Effect of early feed restriction on metabolic programming and compensatory growth in broiler chickens. Poultry Science, 86: 654 - 660. 


\section{تأثير إضافة البوليزايم إلى العلائق المنخفضة البروتين على أداء البط المولار}

عاطف محمد حسن أبو عاثور - سيد عبد الفتاح عبد الرحمن 1 - منال كمال أبو النجا ـ نادر صبحى الفرجانى -

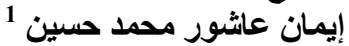

قسم إنتاج الدو اجن و الأسماك ـ كلية الزر اعة - جامعة المنوفية - مصر.

\section{الملخص العربى الجري}

أجريت هذة التجربة لدراسة تأثير لإضافة البوليز ايم فى علائق البط المو لار المنخفضة فى محتواها من البروتين الخام على أداء النمو،

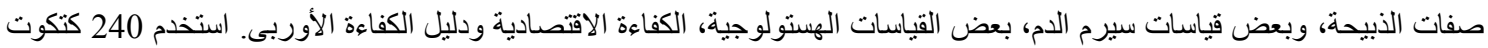

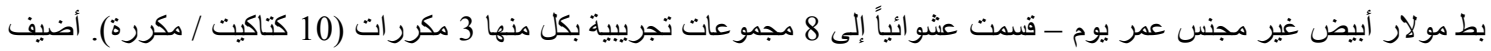

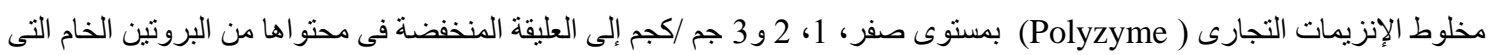

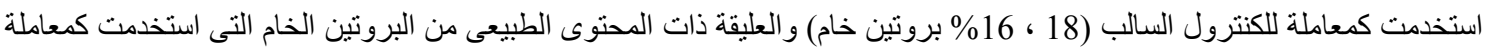

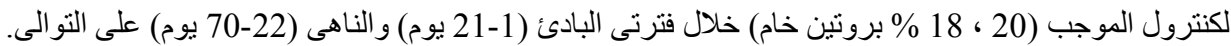

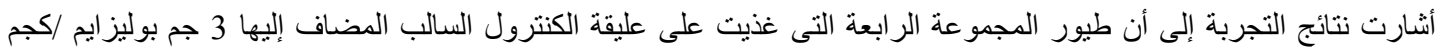

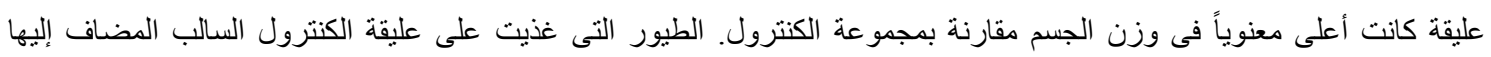
مستويات مختلفة من البوليز ايم استهلكت علائق أكثر معنوياً (P

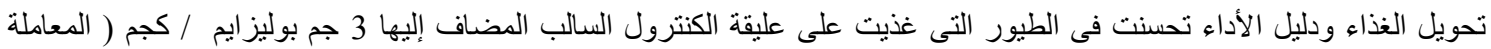

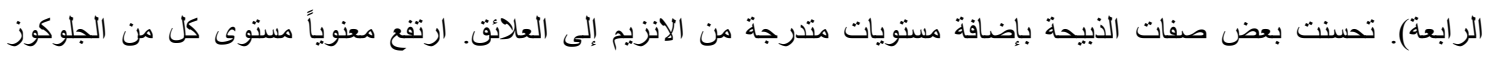

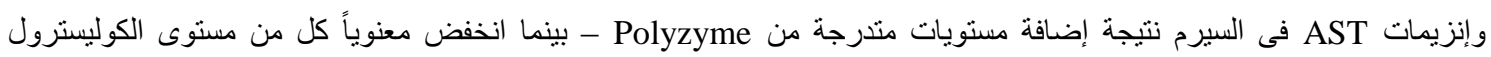

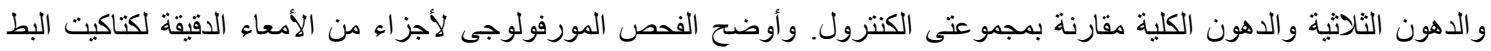

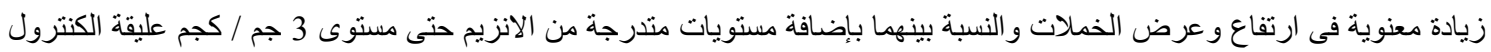

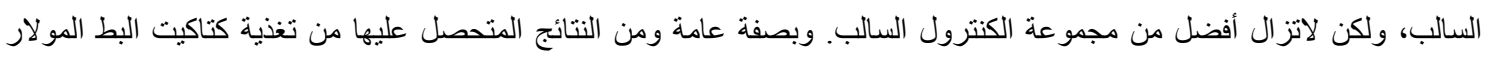

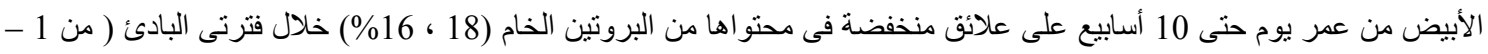

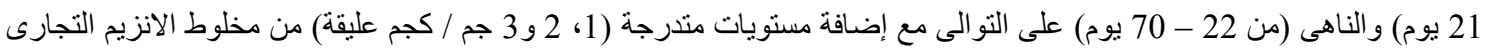
- Polyzyme

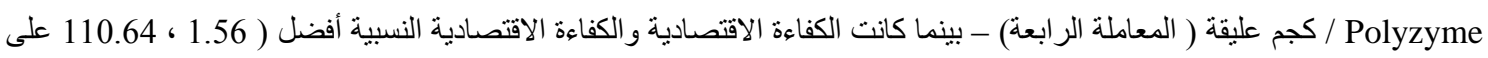
التو الى) فى عليقة المعاملة الثانية المضاف إليها مخلوط الإنزيم التجارى Polyzyme بمعدل 1جم / كجم عليقة مقارنة ببافى المعاملات.

كلية الزراعة - جامعة القاهرة كلية الزر اعة - جامعة المنوفية
أسماء السادة المحكمين

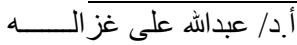

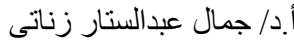

